
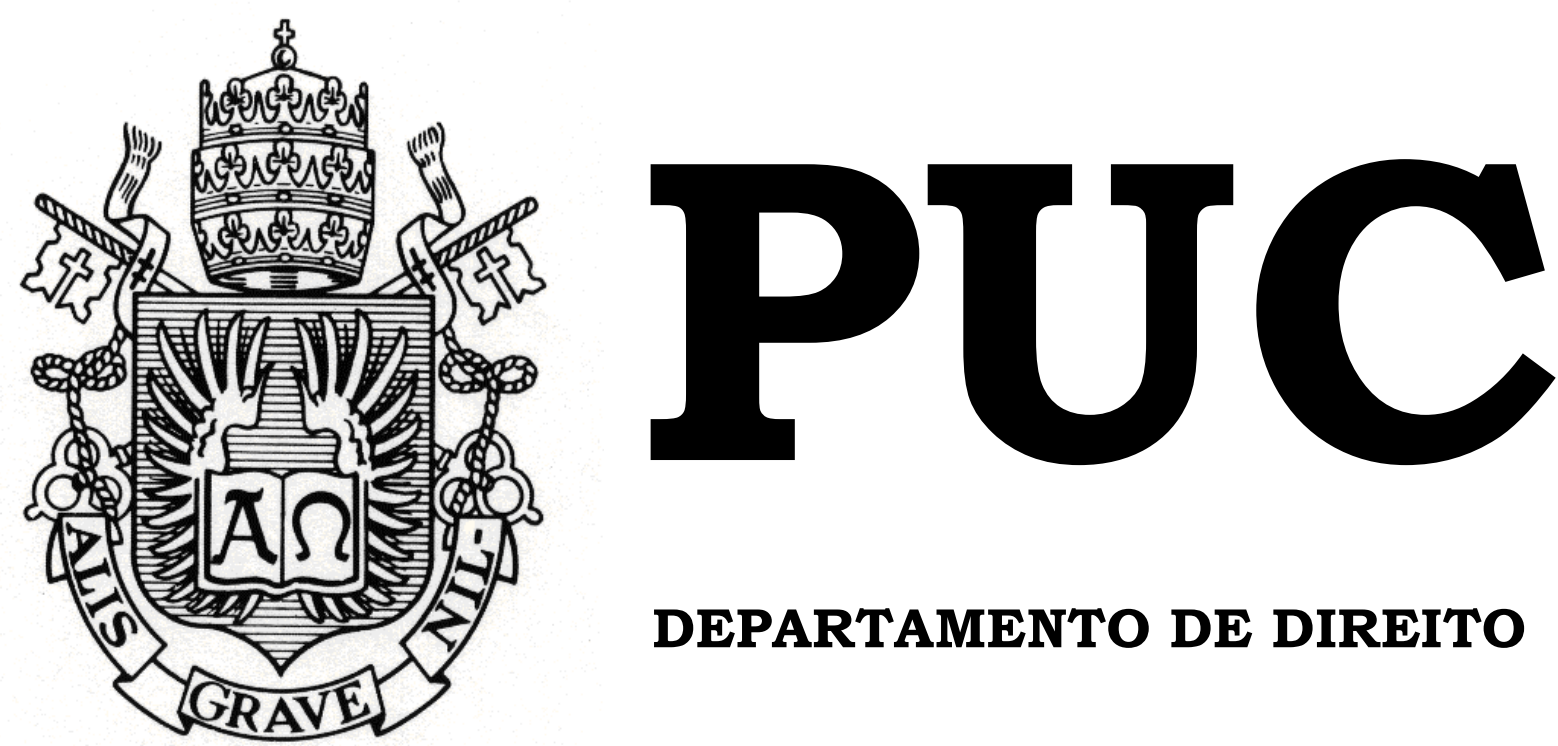

DEPARTAMENTO DE DIREITO

\title{
A ATUAÇÃO DO ESTADO NO DOMÍNIO ECONÔMICO, A SOCIEDADE DE ECONOMIA MISTA E O CONFLITO ENTRE O INTERESSE PÚBLICO E OS INTERESSES PRIVADOS
}

\author{
por \\ LUIZ GUILHERME GAMA DE CASTRO MIGUEL \\ ORIENTADOR(A): Pedro Paulo Salles Cristofaro \\ 2015.1
}

PONTIFÍCIA UNIVERSIDADE CATÓLICA DO RIO DE JANEIRO

RUA MARQUÊS DE SÃO VICENTE, 225 - CEP 22453-900 


\title{
A ATUAÇÃO DO ESTADO NO DOMÍNIO ECONÔMICO, A SOCIEDADE DE ECONOMIA MISTA E O CONFLITO ENTRE O INTERESSE PÚBLICO E OS INTERESSES PRIVADOS
}

\author{
por \\ LUIZ GUILHERME GAMA DE CASTRO MIGUEL
}

Monografia

apresentada

ao

Departamento de Direito da Pontifícia

Universidade Católica do Rio de Janeiro (PUC-Rio) para a obtenção do Titulo de Bacharel em Direito.

Orientador(a): Pedro Paulo Salles Cristofaro 


\section{AGRADECIMENTOS}

Agradeço à família pelo apoio constante e ilimitado.

Agradeço aos amigos e amigas por dividirem os momentos de alegria que dão sentido à vida.

Agradeço à Nandinha pela compreensão e companheirismo.

Agradeço ao professor Pedro Paulo Salles Cristofaro por dividir comigo seu conhecimento jurídico e instigar o pensamento crítico que fundou esse trabalho. 
“A sociedade democrática não se faz automaticamente. Requer duas coisas para ter sucesso. Em primeiro lugar, deve haver um eleitorado interessado e vigilante para escolher, e, em seguida, para controlar pela força da opinião pública, os políticos que elege para gerir os assuntos do país. Em segundo lugar, uma sociedade democrática deve ter partidos políticos honestos e capazes de dar-lhe uma escolha de lideranças alternativas."

\section{— Lee Kuan Yew}

"When the incentives are screwed up, the behavior is screwed up. And it creates a culture where screwed up behavior is normal. It is even praised because it increases profits. Unless you change the incentives, you won't change anything else."

- Michael Lewis

"Charity is injurious unless it helps the recipient to become independent of it." 


\section{RESUMO}

Essa monografia tem como objetivo realizar uma análise crítica da sociedade de economia mista como instrumento de intervenção do Estado no domínio econômico, sob os aspectos de validade e eficiência e com especial atenção ao conflito entre os interesses públicos e os interesses privados. $\mathrm{O}$ esforço se inicia com a exposição da relação histórica entre Estado e economia e a evolução do pensamento político-econômico que nos trouxe ao atual modelo. $\mathrm{O}$ passo seguinte verifica e discute o interesse público, na qualidade de fundamento norteador e limitador de toda atuação estatal, bem como as modalidades disponíveis ao ente público para intervir no domínio econômico. Após a contextualização, adentra-se ao estudo específico das sociedades de economia mista, expondo e discutindo suas características gerais e as peculiaridades inerentes a esse tipo societário diferenciado. A parte final se dedica exclusivamente a apresentação crítica dos desafios de conciliação que a estrutura híbrida gera, focando na complicada relação entre os interesses públicos e os interesses privados no seio societário e seus efeitos na condução da sociedade de economia mista pelo acionista controlador. Ao fim, a conclusão busca dar uma resposta às indagações acerca das situações em que a sociedade de economia mista pode e deve ser utilizada pela Administração Pública.

\section{PALAVRAS-CHAVES}

Intervenção do Estado na Economia - Interesse Público Modalidades de Intervenção - Sociedade de Economia Mista - Atuação Direta do Estado no Domínio Econômico - Princípio da Subsidiariedade Princípio da Supremacia do Interesse Público - Conflito de Interesse Público e Privado - Poder de Controle do Estado - Princípio da Eficiência 


\section{SUMÁRIO}

INTRODUÇÃ

O PAPEL DO ESTADO DO DOMÍNIO ECONÔMICO ..........................10

1.1. Breve história do pensamento político-econômico ……………………... 10

1.2. O interesse público e a atuação estatal ....................................................... 16

1.3. Modos de intervenção do Estado no domínio econômico ................... 21

AS SOCIEDADES DE ECONOMIA MISTA E AS SUAS

PECULIARIDADES .........................................................................................34

2.1. A origem das sociedades de economia mista ………………………....... 34

2.2. As sociedades de economia mista no Brasil ............................................. 38

2.3. Características e peculiaridades da sociedade de economia mista. 42

2.4. Conclusão do capítulo................................................................................ 56

A ESTRUTURA HÍBRIDA E OS DESAFIOS DE CONCILIAÇÃO..58

3.1. O interesse público como fundamento da atividade econômica

estatal e o princípio da subsidiariedade ............................................................... 58

3.2. O princípio da supremacia do interesse público....................................... 62

3.3. O interesse público, o interesse social e o poder de controle ............67

3.4. A busca pelo lucro, o princípio da eficiência e a concorrência ........74

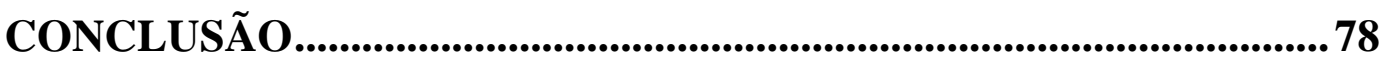

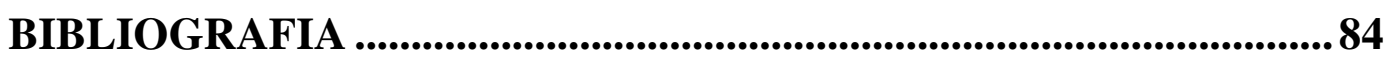




\section{INTRODUÇÃO}

O título do presente trabalho introduz um conflito de séculos de idade. Ao longo desses séculos, filósofos, pensadores sociais, políticos, juristas e economistas puseram em pauta de discussão abordagens distintas e julgamentos com vieses próprios sobre o interesse dos particulares e seu maior "algoz", o interesse público.

Muito embora por vezes de forma implícita ou mesmo inconscientemente presentes no discurso, foram opiniões sobre a natureza e o status do interesse público que delinearam o pensamento político-social em cada época, os quais, por sua vez, moldaram o que cada geração entendia por Estado e seus limites.

O status quo do interesse público é assim resultado, ainda que com absoluta certeza temporário, de um processo de evolução. Trata-se de mais uma linha de chegada que requer para sua compreensão e, principalmente, crítica, uma visão das fases atravessadas por esse elemento crucial ao surgimento, à existência e à justificativa do Estado e seus meios de atuação.

Não por outra razão, sem fugir do objetivo precípuo de compreender e criticar o regime jurídico das sociedades de economia mista - meio de atuação que se pretende aqui abordar em função de peculiaridades que exaltam o conflito em questão -, a exposição e discussão em torno do tema interesse público será um coadjuvante de destaque nesse estudo.

Dividiremos o trabalho em três partes.

A primeira parte será dedicada à exposição do panorama histórico do pensamento político-econômico, com o objetivo de verificar a abordagem dispensada à relação entre Estado e economia em cada época, bem como se, por quê, como e com qual intensidade o Estado interveio no domínio econômico. Sendo a economia, ou o mercado, o espaço onde predominam os interesses privados e o Estado um ente dirigido pelo interesse público, tal relação sempre teve o fio da balança ajustado 
conforme a prioridade que cada sociedade desejava oferecer a cada um desses interesses. A questão sempre se fez presente nas ciências humanas e em movimento quase que pendular Estado e economia, público e privado, estiveram mais próximos ou mais distantes: desde a era feudal até o Estado Democrático de Direito que vivemos hoje, passamos pelo Estado Absolutista, o Estado Liberal e o Estado Social.

Em seguida, traremos a questão para os dias atuais explorando a dificuldade dos doutrinadores para definir interesse público e julgar sua eventual prioridade em relação aos interesses privados - princípio da supremacia do interesse público. A falta de uma definição clara e uniforme, bem como compreensões equivocadas do princípio e sua aplicação, faz germinarem discussões não só sobre o limite, mas também sobre o ponto de partida da atuação da Administração Pública. Nessa etapa, introduziremos o debate sobre o que deve orientar a atuação da administração pública e quais são os verdadeiros princípios norteadores.

Para fechar o tópico e principiar o estudo das sociedades de economia mista, serão apresentadas e distinguidas as principais modalidades de intervenção do Estado no domínio econômico.

A segunda parte abordará mais especificamente o objeto do presente trabalho, expondo a origem e a evolução no Brasil e no mundo do instituto jurídico da sociedade de economia mista - uma história que remonta ao século XVI, com as grandes navegações e a Companhia das Índias Orientais. Na sequência serão apresentadas as principais características contemporâneas do modelo, um dos modos de atuação direta na economia disponíveis ao Estado brasileiro no atual sistema jurídico constitucional.

A partir de tais características serão reveladas as peculiaridades do instituto, derivadas em sua grande maioria dos efeitos da participação do erário no capital social e das atribuições da administração pública dentro da sociedade. Nessa etapa, exploraremos o regime jurídico aplicável, o 
controle da sociedade pelo Estado, a criação através de lei e o fim de interesse público que deve orientar sua constituição e direção.

A terceira parte - a mais controversa desse trabalho - será destinada a discutir os problemas e desafios que emergem da estrutura híbrida e da necessidade de sopesar constantemente os interesses públicos, que devem dirigir toda atuação estatal, e os interesses dos acionistas, aos quais estão adstritos os administradores e os sócios controladores de toda sociedade anônima - categoria na qual, vale frisar, encontra-se incluída a sociedade de economia mista.

Voltaremos então ao conceito de interesse público como norteador de toda atuação estatal, inclusive na qualidade de agente econômico, no contexto da problemática que envolve a sua constante contraposição aos interesses da sociedade e dos acionistas. Pretende-se, nesse ponto, analisar a existência de eventual hierarquia entre o interesse público e o interesse particular, discutindo-se a força do princípio da supremacia do interesse público, bem como sua aplicabilidade à direção das sociedades de economia mista.

A discussão se estenderá a como harmonizar a busca pelo lucro característica essencial das sociedades empresárias - e o interesse público visado com a constituição da sociedade de economia mista, dispensando-se atenção especial à importância desse ajuste para o equilíbrio de mercado e a manutenção da livre concorrência.

O encerramento da terceira parte delineará a discussão que envolve o Estado-empresário e o princípio da eficiência, em um válido questionamento da capacidade competitiva do Estado como agente econômico e da eficácia de tal instrumento interventivo na execução das políticas públicas.

Nesse esforço, partindo da contextualização histórica do intervencionismo estatal na economia, atravessando discussões filosóficas, políticas, econômicas e jurídicas acerca de seu princípio norteador, e chegando à análise das contradições na aplicação do instrumento da 
sociedade de economia mista em suas características contemporâneas, acredita-se estar abrangendo o tema da maneira mais completa. É essa completude que permitirá uma conclusão clara sobre a validade, as eficiências, deficiências e limitações do peculiar modelo de sociedade de economia mista. 


\section{PRIMEIRA PARTE \\ O PAPEL DO ESTADO DO DOMÍNIO ECONÔMICO}

\subsection{Breve história do pensamento político-econômico}

Não é novidade para as ciências humanas o debate sobre a extensão e o formato que deve ter a relação entre o Estado e a economia ${ }^{1}$. Ao longo dos últimos séculos, e principalmente após o surgimento do Estado Liberal, a compatibilização da direção do Estado e dos interesses econômicos sempre manteve acalorada uma discussão que envolve filósofos, sociólogos, economistas, políticos e juristas².

As posições assumidas por cada um desses pensadores, ainda que de forma subjacente e nem sempre explícita, fundam-se em opiniões divergentes sobre outras relações que precedem e se correlacionam com a primeira: a relação entre o Estado e os cidadãos, o Estado e a sociedade civil, o público e o privado.

Essa última tem origens que remontam à Grécia antiga, onde a distinção entre os campos público e privado acompanhou o nascimento da polis. A vida pública do cidadão ganhou importância sobre a vida privada e a possibilidade de se envolver com os assuntos coletivos era vista como o próprio exercício da liberdade. Mais tarde, as dimensões distintas de público e privado tornaram-se ainda mais relevantes ao dar origem à grande divisão entre Direito Público e Direito Privado, classificação que remonta ao Digesto, uma parte do Corpus Iuris Civilis romano ${ }^{3}$.

\footnotetext{
${ }^{1}$ CARVAlHO FILHO, José dos Santos. Manual de Direito Administrativo. $25^{\text {a }}$ ed.. São Paulo: Atlas, 2012, p. 897.

${ }^{2}$ A questão está intimamente ligada à Teoria Geral do Estado, noção que, segundo o professor Dalmo Dallari, "é uma disciplina de síntese, que sistematiza conhecimentos jurídicos, filosóficos, sociológicos, políticos, históricos, antropológicos, econômicos, psicológicos, valendo-se de tais conhecimentos para buscar o aperfeiçoamento do Estado, concebendo-o, ao mesmo tempo, como um fato social e uma ordem, que procura atingir os seus fins com eficácia e com justiça." (DALlARI, Dalmo de Abreu. Elementos da Teoria Geral do Estado. São Paulo: Saraiva, 2003, p. 2).

SARMENTO, Daniel. Interesses públicos "versus" interesses privados na Perspectiva da Teoria e da Filosofia Constitucional. In: SARMENTO, Daniel (Org.). Interesses Públicos versus Interesses
} 
Os debates acerca da interação entre Estado e cidadãos deram origem a importantes aspectos das ciências humanas e transbordaram para os moldes da relação entre Estado e economia.

O ente Estado, conforme concebido atualmente, surgiu com o fim da Idade Média, quando o regime feudal e suas estruturas de poder fundadas na propriedade territorial - instituto de caráter privado - foram substituídos por um regime que começou a tornar mais complexa a relação entre o público e o privado ${ }^{4}$.

A ascensão do absolutismo concentrou nas mãos de um só homem um poder que antes esteve espalhado nas mãos de muitos. O pluralismo político e a dispersão de autoridade que marcaram o período feudal foram trocados pelo paternalismo e a concentração absoluta de forças nas mãos do monarca.

A confusão entre os campos públicos e privado acabou por estabelecer uma identificação física do monarca com o próprio Estado. Não fosse o outro lado da moeda, até se poderia advogar um caráter essencialmente privado da lógica aplicada às relações políticas nessa primeira face do Estado Moderno, essencialmente personalista. Entretanto, alicerçado na ideia de soberania, o regime absolutista tornou incontrastável o poder estatal e fez predominar a autoridade pública sobre a vontade dos indivíduos. $\mathrm{O}$ respeito à esfera privada se viu enfraquecido e as "razões de Estado", na expressão cunhada por Maquiavel, passaram a permitir o uso legítimo da extrema violência em defesa da ordem e da segurança. O Estado absolutista evidenciou e fortaleceu assim sua expressão pública, ainda que marcada pela pessoalidade.

Durante esse período, a mesma lógica, calcada na superioridade do público, na predominância da vontade do Estado e no paternalismo, era aplicada à interação entre o "ente superior" e a economia. Não à toa, foram os séculos de domínio e envolvimento sufocante do Estado no mercado -

Privados: Desconstruindo o Princípio da Supremacia do Interesse Público. Rio de Janeiro: Lumen Iuris, 2005, p. 23-116.

${ }^{4}$ DALLARI, Dalmo de Abreu. Op. cit., p. 275. 
ambiente eminentemente privado - que deram impulso ao que se tornaria a revolução liberal.

Foi somente no seio do Estado Liberal-Burguês, fundado pelas revoluções inglesa, francesa e norte-americana dos séculos XVIII e XIX, que uma separação mais nítida entre público e privado pôde ser observada.

O movimento de reação ao autoritarismo absolutista limitou o poder estatal em prol das liberdades dos indivíduos ${ }^{5}$. Certos direitos fundamentais foram originalmente assentados, focando na valorização do indivíduo, e a interferência estatal nas relações travadas entre os particulares deixou de ser cabível e aceitável. Separou-se, portanto, de forma rígida, os campos público e privado.

De acordo com Adam Smith, um típico representante do liberalismo econômico, passou a caber ao Estado tão somente o cumprimento de três deveres. O primeiro consiste na promoção da segurança externa contra a invasão por outras sociedades. O segundo é a segurança interna, o dever de proteger cada membro da sociedade das injustiças e opressões perpetradas por qualquer outro membro. Por fim, o dever de erigir e manter obras ou instituições públicas que nunca serão do interesse de investidores privados, por não serem lucrativas. ${ }^{6}$

Os reflexos ${ }^{7}$ na economia foram imediatos e amparados pela crença na "mão invisível do mercado" ". A essa cabia equacionar todas as questões

\footnotetext{
5 "Partindo mais especificamente do Estado moderno, e a partir do final do século XVIII, vicejou nitidamente a supremacia da teoria do 'liberalismo econômico', divulgada e praticada graças à doutrina de ADAM SMITH, estampada em sua obra 'A riqueza das nações', de 1776. Por essa doutrina que, diga-se de passagem, atendia aos interesses da burguesia que passava a dominante, cada indivíduo deve ter liberdade de promover seus interesses, porque ninguém melhor que ele para avaliá-los. Ao Estado não caberia a interferência nem a regulação da economia; limitava-se apenas a uma postura de mero observador da organização processada pelos indivíduos. O laissez faire, laissez passer dava bem a ideia de passividade do Estado diante dos fenômenos econômicos e sociais.” (CARVALHO FILHO, José dos Santos. Op. cit., p. 897)

${ }^{6}$ VENANCIO FILHO, Alberto. A Intervenção do Estado no Domínio Econômico - O Direito Público Econômico no Brasil. Ed. Fac-similiar da de 1968, Rio de Janeiro: Renovar, 1998, p. 4.

${ }^{7}$ Possivelmente "reflexo" não é a palavra mais adequada. A Revolução Liberal-Burguesa tem esse nome exatamente pelo protagonismo assumido pela burguesia no movimento que levou ao fim do regime absolutista e à separação rígida entre público e privado proposta pelo novo ordenamento jurídico. Dentre outros, a sufocante intervenção do Estado Absolutista no domínio econômico e nas transações particulares travadas pelos burgueses foi um dos elementos determinantes para a insurreição liderada pela classe social que dominava as relações econômicas da época, como explica Dalmo de Abreu Dallari. Não é descabido, portanto, assumir que a mudança na relação do
} 
sociais e econômicas, restando ao Estado a função única e exclusiva de garantir as condições necessárias para que ela pudesse atuar livremente, isto é, preservar e assegurar a liberdade de comércio e contrato.

A partir desse momento de separação absoluta entre os espaços público e privado e consolidação do regime capitalista nos países ocidentais, a relação turbulenta entre Estado e economia passou a receber ainda mais destaque e foi elevada à posição central que ocupa hoje dentro das ciências sociais.

$\mathrm{O}$ século XX ainda acrescentaria muito combustível à discussão, tendo sido palco de outras importantes transformações no pensamento político-econômico e no papel designado ao Estado.

O Estado Liberal trouxe benefícios inegáveis, permitindo um rápido progresso econômico, que resultou nas revoluções industriais, e uma evolução política e social com consolidação do poder da lei que tomou o lugar do poder marcado pela pessoalidade ${ }^{9}$.

Ao mesmo tempo, também criou as condições para sua própria falência. A valorização do individuo transmudou-se no ultraindividualismo ${ }^{10}$ e a limitação do poder estatal o impedia de atuar como redentor de classes menos favorecidas. A burguesia, classe revolucionária de outrora e agora detentora das propriedades industriais surgidas com a Revolução Industrial, dominava o poder político e não permitia que o Estado garantisse que melhores condições de trabalho fossem oferecidas ao proletariado, massacrado pela gigantesca oferta de mão-de-obra e a remuneração ínfima ${ }^{11}$. Estavam plantadas as sementes para os movimentos sociais do fím do século XIX e início do século XX. ${ }^{12}$

Estado com a economia tenha sido causa e não consequência da completa alteração no relacionamento entre Estado e cidadãos e da separação entre os campos do público e do privado.

${ }^{8}$ VENÂNCIO FILHO, Alberto. A Intervenção do Estado no Domínio Econômico - O Direito Público Econômico no Brasil. Op. cit., p. 4.

${ }^{9}$ Com as reservas necessárias, foi durante o surgimento do Estado Liberal em que se começou a ensaiar a proclamação da emblemática máxima do Estado Democrático de Direito de que "todos são iguais perante a lei".

${ }^{10}$ DALLARI, Dalmo de Abreu. Op. cit., p. 277.

11 “A pretensa liberdade na ordem econômica conferida pelo Estado aos indivíduos surtiu efeito contrário, revelando-se forma de alargar os abismos entre as classes sociais e tornando o pobre 
A crise do Estado Liberal cedeu espaço para o aparecimento do Estado Social, ou Welfare State, como ficou conhecido o modelo resultante da política do New Deal, implementada pelo governo norte-americano no pós-guerra. Em meados do século XX, pressionado pelas demandas de classes inferiores trazidas à pauta pela universalização do voto, pelo surgimento do comunismo e pelos efeitos catastróficos da Primeira Guerra Mundial, o Estado passou a intervir nos diversos domínios, deixando de lado o posto de coadjuvante e assumindo a função de protagonista das relações econômicas ${ }^{13}$.

Suas funções não mais se resumiam às meras abstenções impostas anteriormente, mas exigiam prestações positivas de novos e mais serviços públicos. As novas atribuições assumidas pelo Estado do Bem-Estar Social levaram ao seu inevitável crescimento e, conforme ele ganhava espaço, a proteção às liberdades até ali conquistada ia sendo relativizada pela instituição de normas reguladoras e redução da autonomia das partes.

Não havia mais qualquer área protegida e alheia à intervenção estatal. Vivia-se a fase do dirigismo econômico, no qual o Poder Público não mais se limitava à polícia e à administração da justiça: financiava, fabricava, comerciava, gerava a economia ${ }^{14}$.

Mas novamente, do próprio regime floresceu seu declínio. A euforia logo deu lugar a críticas ao Estado interventor e principal ator econômico. No final do século XX, o ceticismo sobre a capacidade do Estado de ser mais eficiente que a "mão invisível" como racionalizador das forças

\footnotetext{
cada vez mais pobre e o rico cada vez mais abastado. A liberdade para as classes desfavorecidas transformou-se em escravidão. Definitivamente, o Estado não ficar indiferente ao crescimento das desigualdades sociais." (CARVALHO FILHO, José dos Santos. Op. cit., p. 898)

${ }^{12}$ VENÂNCIO FILHO, Alberto. A Intervenção do Estado no Domínio Econômico - O Direito Público Econômico no Brasil. Op. cit., p. 7-12.

13 “(...) a partir da Primeira Guerra Mundial, verificamos a introdução, nas Constituições de diversos países, de preceitos disciplinando a intervenção estatal na economia, visando a suprir as deficiências da iniciativa privada e oferecer à sociedade determinados serviços que não eram suficientemente providos pelas empresas privadas." (EIZIRIK, Nelson. A Lei das S/A Comentada, Volume III. $1^{\text {a }}$ ed.. São Paulo: Quartier Latin, 2011, p. 285)

${ }^{14}$ BARROS, Alberto Moniz da Rocha. O Poder Econômico do Estado Contemporâneo e seus Reflexos no Direito. São Paulo: Revista dos Tribunais, 1953, p. 259.
} 
econômicas e promotor do desenvolvimento estampou-se na queda do muro do Berlim e no fim da União Soviética.

As falhas no cumprimento das inúmeras obrigações assumidas tornaram irremediável a associação da imagem do Estado à burocracia excessiva, à ineficiência e ao desperdício. O pêndulo apontou novamente para o campo privado e nos trouxe ao atual momento.

Ganharam forças os movimentos de privatização ao redor do mundo e diversas atividades econômicas que estavam sendo desenvolvidas pelo Estado foram transferidas de volta para a administração dos particulares.

O Estado adquiriu novamente uma feição subsidiária, coadjuvante, devolvendo aos indivíduos o papel principal. Contudo, dessa vez não se deixou de reconhecer a necessidade de que o ente estatal atue para prevenir eventuais falhas inerentes à liberdade mercadológica que levaram à falência do Estado Liberal-Burguês ${ }^{15}$.

Na experiência nacional, após períodos de intenso intervencionismo durante a Era Vargas e o regime ditatorial, a Constituição de 1988 sistematizou a atuação do Estado na economia, limitando seu caráter empresário $^{16}$ e dando traços mais fortes às atividades regulatórias e fiscalizadoras ${ }^{17}$.

\footnotetext{
15 "O Estado surgido com o advento do sufrágio universal é um fenômeno heterogêneo, sendo-lhe atribuída uma série de denominações e subdivisões ao longo do tempo e dos espaços políticogeográfico: Estado de bem-estar, Estado social, pós-capitalista, pós-industrial, intervencionista, propulsivo, administrativo, gestor, incitador, dirigente e, mais recentemente, regulador, pósmoderno, etc. A bem da verdade, todas estas denominações estão ao mesmo tempo certas e erradas. Erradas, porque pretendem, tomando por base apenas determinado momento da história e/ou dados países, congelar aspectos de realidades multifacetárias e dinâmicas. Por outro lado, todas estas denominações também são verdadeiras, já que são exatamente a diversidade e a flexibilidade que caracterizam o Estado Democrático pluriclasse, do qual não existe um modelo único.” (ARAGÃO, Alexandre Santos de. Agências Reguladoras e a Evolução do Direito Administrativo Econômico, $2^{\mathrm{a}}$ Ed., Rio de Janeiro: Forense, 2006, p. 54-55).

${ }^{16}$ Nesse sentido, veja-se a lição de Luis Roberto Barroso sobre a alteração constitucional promovida pela Constituição de 1988 ao tratar da atuação do Estado como agente econômico: "É bem de ver que, embora a referência à livre-iniciativa seja tradicional aos textos constitucionais brasileiros, a Carta de 1988 traz uma visão bem diversa da ordem econômica e do papel do Estado, em contraste com os modelos anteriores. Já não se concede mais, como fazia a Carta de 1967/69, ampla competência na matéria ao legislador ordinário, ao qual era reconhecida até mesmo a possibilidade de instituir monopólios estatais. As exceções ao princípio da livre iniciativa, portanto, haverão de estar autorizadas pelo próprio texto da Constituição de 1988 que o consagra. Não se admite que o legislador ordinário possa livremente excluí-la, salvo se agir fundamento em outra norma constitucional específica." (BARROSO, Luís Roberto. A Ordem Econômica Constitucional e os Limites à Atuação do Estatal no Controle de Preços. In: ARAGÃO, Alexandre
} 
Assim, nosso modelo constitucional consagrou os elementos básicos de uma economia de mercado, sustentados na livre iniciativa e na valorização do trabalho humano e desdobrados e concretizados na proteção à propriedade privada, na livre concorrência, na liberdade de contratação, no livre exercício de atividades econômicas e na garantia de direitos aos trabalhadores ${ }^{18}$. Ao mesmo tempo, estabeleceu também determinados princípios $_{\text {corretivos }}^{19}$ para temperar tais liberdades, os quais simultaneamente dirigem e limitam a atuação do Estado. Procurou-se assim um meio termo entre o liberalismo e o intervencionismo ${ }^{20}$.

Nos tópicos a seguir, trataremos dos meios pelos quais o Estado pode intervir no mercado para promover os princípios da ordem econômica constitucional, bem como das razões que demandam e justificam a atuação estatal.

\subsection{O interesse público e a atuação estatal}

Conforme exposto acima, o Estado percorreu uma trajetória pendular desde o seu surgimento até os dias atuais. Começou absolutista, com o predomínio total da força estatal representada na pessoa do monarca; foi liberal, quando lhe cabiam funções mínimas, em um período de consolidação dos direitos individuais; tornou-se social, já no século XX,

dos Santos de (Coord.). Revista de Direito da Associação de Procuradores do Novo Estado do Rio de Janeiro: Direito da Regulação, v. XI, Rio de Janeiro: Lumen Iuris, 2002, p. 47-48).

${ }^{17}$ EIZIRIK, Nelson. Op. cit., p. 286.

${ }^{18}$ BARROSO, Luís Roberto. A Ordem Econômica Constitucional e os Limites à Atuação Estatal no Controle de Preços. Op. cit., p. 47.

19 “O princípio da liberdade de iniciativa é temperado pelo da iniciativa suplementar do Estado; o da liberdade de empresa pelo da sua função social; os da liberdade de lucro e de competição são moderados com o da repressão ao abuso do poder econômico; a liberdade de contratação é limitada pelo princípio da valorização do trabalho; e o princípio da propriedade privada é temperado pelo da função social da propriedade." (EIZIRIK, Nelson. Op. cit., p. 290). No mesmo sentido: MOREIRA NETO, Diogo de Figueiredo. Ordem Econômica e Desenvolvimento na Constituição de 1988. Revista de Direito da Procuradoria Geral do Estado do Rio de Janeiro, Rio de Janeiro, v. 42, 1990, pp. 57-67.

20 "Por decorrência, reconhece-se que a realização dos direitos fundamentais exige não apenas um Estado de Direito caracterizado pela ausência de atuação em face dos problemas e da realidade socioeconômica. A finalidade buscada não é apenas limitar o poder estatal. É necessário limitar o poder estatal, mas também é indispensável que o Estado seja um instrumento de promoção do desenvolvimento econômico e social." (JUSTEN FILHO, Marçal. Curso de Direito Administrativo, $8^{\mathrm{a}}$ ed., rev. e ampl.. Belo Horizonte: Editora Fórum, 2012, p. 76). 
assumindo funções na superação das desigualdades e intervindo no mercado como promotor do desenvolvimento econômico e social; adentrou ao novo século, neoliberal, concentrando-se nas atividades de regulação e fomento e reservando novamente aos particulares a atuação direta como agente econômico.

Durante esse tempo suas atribuições variaram, mas " não há qualquer sintoma de que esteja em processo de extinção ou de que a ele será reservado um papel secundário" ${ }^{21}$. Ainda há uma função importante reservada ao Estado que deve ser exercida consoante as diretrizes e nos limites estabelecidos pela nova configuração constitucional.

Portanto, antes de adentrar à exposição dos modos de intervenção do Estado na economia, faz-se imprescindível discutir e compreender qual é o principal norteador - e consequente limitador - da atividade estatal nessa nova fase. A promoção e proteção do interesse público são os fundamentos do $E \operatorname{stado}^{22}$ e dão à Administração Pública seu caráter de pessoa jurídica diferenciada $^{23}$, constituindo um conceito basilar que permeará todo esse estudo.

Sem prejuízo da certeza que se tem quanto à sua função primordial, enorme é a dificuldade dos doutrinadores de traçarem precisamente seus contornos. Por se tratar de um conceito jurídico indeterminado ${ }^{24}$, o interesse público tem seu conteúdo naturalmente afastado da exatidão, fato que é ainda mais ressaltado pelas suas características específicas.

Nessa esteira, Calixto Salomão Filho duvida até mesmo da possibilidade de se tecer um conceito fechado ao afirmar que " $a$ definição

\footnotetext{
21 BARROSO, Luís Roberto. Curso de Direito Constitucional Contemporâneo: os conceitos fundamentais e a construção do novo modelo, 4 ed., São Paulo: Saraiva, 2013, p. 91-92.

22 “As atividades administrativas são desenvolvidas pelo Estado para benefício da coletividade. Mesmo quando age em vista de algum interesse estatal imediato, o fim último de sua atuação deve ser voltado para o interesse público. E se, como visto, não estiver presente esse objetivo, a atuação estará inquinada de desvio de finalidade." (CARVALHO FILHO, José dos Santos. Op. cit., p. 32) ${ }^{23}$ JUSTEN FILHO, Marçal. Op. cit., p. 114.

24 "São expressões vocabulares que comportam indeterminação de sentido, o que exige que o aplicador produza sua delimitação para o caso concreto. (...) A ausência de determinação precisa não é um defeito do conceito, mas um atributo destinado a permitir sua aplicação mais adequada caso a caso. A indeterminação dos limites do conceito propicia a aproximação do sistema normativo à riqueza do mundo real.” (Ibid., p. 208)
} 
de interesse público é multifacetada - ora política, ora econômica -, não permitindo que a mesma seja colocada em termos precisos". Para o ilustre professor, "a experiência prática põe em sérias dúvidas a existência de um conceito - verdadeiro e coerente - de interesse público para fins de intervenção do Estado na econômica" $" 25$.

Contudo, a busca por uma definição mais precisa é essencial para determinar seu alcance e permitir o controle de validade dos atos governamentais. Defini-lo é talvez o principal dilema do Direito Administrativo.

O primeiro obstáculo que vale contornar consiste no equívoco comum que concebe como interesse público todo e qualquer interesse tutelado pelo Estado. A solução de origem doutrinária esteia-se na diferenciação entre interesse público primário e interesse público secundário, conforme classificação cunhada por Renato Alessi e difundida no direito pátrio por Celso Bandeira de $\mathrm{Mello}^{26}$.

O primeiro é o interesse público propriamente dito, o interesse da coletividade, de toda a sociedade, que transcende o interesse individual singularmente considerado. Embora não seja seu titular, é a tutela desses interesses a razão de ser do Estado, o que justifica sua existência e essência. $\mathrm{O}$ segundo remete aos interesses individuais e particulares da Administração Pública, próprios do $\operatorname{Estado}^{27}$ enquanto pessoa jurídica titular de direitos e similares aos interesses de qualquer outro sujeito. São interesses como, por exemplo, a busca pela maximização da receita e redução de despesas do erário. Alguns autores defendem que sequer tem

\footnotetext{
${ }^{25}$ SALOMÃO FILHO, Calixto. Regulação da Atividade Econômica (Princípios e Fundamentos Jurídicos), $2^{\mathrm{a}}$ ed., rev. e ampl., São Paulo: Malheiros Editores, 2008, p. 23. Nesse mesmo sentido, veja-se o ceticismo de Friedrich Hayek com relação ao conceito de interesse público: "The commom welfare or the public good has to the present time remainded a concept most recaciltrant to any precise definition and therefore capable of being given almost any concept suggested by the interests of the ruling group" (HAYEK, Friedrich. Law, Legislation and Liberty, v. II. Chicago: The University of Chicago Press, 1976, p. 01).

${ }^{26}$ BANDEIRA DE MELLO, Celso Antonio. Curso de Direito Administrativo, 30 ed., São Paulo: Malheiros, 2013, p. 66.

${ }^{27}$ Trata-se dos interesses da pessoa jurídica de direito público dentro de uma relação jurídica, quer seja ela a União, um Estado, o Distrito Federal, um Município, ou qualquer de suas autarquias.
} 
natureza pública e por se tratarem da atuação privada da Administração Pública são meras conveniências circunstanciais egoísticas ${ }^{28}$.

A distinção é indispensável para a perfeita compreensão do princípio da indisponibilidade, intimamente relacionado à questão, eis que suprime do Estado a faculdade de dispor sobre interesses públicos. Obviamente, tal princípio só se aplica aos interesses públicos primários, que não são de titularidade da Administração Pública nem de seus agentes, mas que devem ser por estes protegidos e perseguidos em prol da coletividade, a verdadeira titular $^{29}$. A conclusão é que a impossibilidade de disposição faz inclusive com que, por vezes, o interesse secundário seja sacrificado para a integral satisfação do interesse primário ${ }^{30}$.

Feito o ponto de que o interesse público não se confunde com o interesse do Estado, convém retornar à conceituação do que seria o interesse público primário.

De acordo com o publicista Celso Antônio Bandeira de Mello, partidário da corrente doutrinária dominante, o interesse público, “do todo, do conjunto social, nada mais é que a dimensão pública dos interesses individuais, ou seja, dos interesses de cada individuo enquanto partícipe da Sociedade (entificada juridicamente no Estado)"31.

Tal definição propõe uma diferenciação entre os interesses dos indivíduos singularmente considerados e os interesses desses mesmos indivíduos enquanto membros de uma coletividade maior em que estão inseridos. A esse último dá-se o nome de "interesse público". O exemplo citado pelo autor esclarece sua opinião e merece uma menção resumida: um indivíduo certamente não terá interesse em ser desapropriado para a construção de uma estrada, mas certamente também não poderá ter interesse em que não haja o instituto da desapropriação.

\footnotetext{
${ }^{28}$ JUSTEN FILHO, Marçal. Op. cit., p.120.

${ }^{29}$ CARVAlHO FILHO, José dos Santos. Op. cit., p. 34; BANDEIRA DE MELlO, Celso Antônio. Op. cit., p. 76.

${ }^{30}$ Exemplos dessa situação são momentos em que a Administração Pública tenha que aumentar os gastos com uma determinada obra, onerando seu caixa, ou conceda benefícios fiscais de modo a fomentar determinada atividade, abdicando de receitas, entre outros.

${ }^{31}$ BANDEIRA DE MELLO, Celso Antônio. Op. cit., p. 61.
} 
Dessa concepção majoritária do interesse público como a dimensão pública dos interesses individuais, que resulta em um interesse comum a todos, é que deriva o princípio da supremacia do interesse público.

De extrema importância para o tema do presente estudo, o conceito é exatamente aquele que sua denominação sugere: o interesse da coletividade deve sempre se sobrepor sobre o interesse particular; e a explicação perpassa a simples noção de que a parte que constitui o todo jamais poderá a ele se sobrepor.

Ao argumentar sua importância para o direito, Bandeira de Mello afirma se tratar de um "princípio geral de Direito inerente a qualquer sociedade", um verdadeiro "pressuposto de uma ordem social estável, em todos e cada um possam sentir-se garantidos e resguardados" ${ }^{32}$.

Defendido por diversos outros nomes importantes do direito administrativo $^{33}$ com as devidas variações de intensidade e argumentos, tal princípio é frequentemente associado a determinadas prerrogativas da Administração Pública na qualidade de guardiã dos interesses da coletividade" ${ }^{\prime 34}$. Do mesmo postulado também decorreria a verticalidade e o desequilíbrio em favor do Estado nas relações travadas com os administrados ${ }^{35}$.

Dessa maneira, conquanto subsistam contendas acerca da exata acepção do interesse público (alguns defendem que se trata da soma dos interesses privados, outros que se trata de uma verificação do interesse da maioria), a concepção clássica converge para um ponto: o interesse público transcende o interesse puramente privado e singular e representa o

\footnotetext{
32 Ibid., p. 99 e 70.

${ }^{33}$ Além de Bandeira de Mello, são também defensores do princípio Hely Lopes Meirelles, Fabio Medina Osório, José dos Santos Carvalho Filho, dentre outros.

${ }^{34}$ Trata-se de uma relação que alguns confundem entre causa e consequência ou consequência e causa, isto é, se o princípio decorre da existência das prerrogativas ou se as prerrogativas decorrem da existência do princípio.

${ }^{35}$ SARMENTO, Daniel. Op. cit., p. 23. Defesas de ambos os pontos podem ser encontradas em: BANDEIRA DE MELLO, Celso Antonio. Op. cit., p. 70-73; MEIRELLES, Hely Lopes. Direito Administrativo Brasileiro, 39ª ed.. São Paulo: Malheiros, 2013, p. 110-111.
} 
“interesse geral da sociedade"36. Esse é ponto de convergência que a faz alçar o interesse público a uma categoria hierarquicamente superior a categoria dos interesses particulares, dando origem e sustentação ao princípio que enxerga a supremacia daquele sobre esse, e, por sua vez, ampara o favorecimento dos propósitos do Estado na qualidade de defensor da coletividade.

Sem embargo de mais adiante nesse trabalho, na esteira de vozes autorizadas do direito ${ }^{37}$, questionar a referida supremacia - especialmente aquela que se afirme em abstrato e antecipadamente -, convém por ora trabalhar com o conceito de interesse público primário como aquele que interessa à sociedade como um todo, um interesse supraindividual ${ }^{38}$.

\subsection{Modos de intervenção do Estado no domínio econômico}

Verificamos que uma evolução pendular do pensamento políticoeconômico nos trouxe até o presente momento. A Constituição de 1988 colocou o setor privado e os particulares de volta no papel principal da ordem econômica $^{39}$. Entretanto, ao contrário dos regimes estritamente liberais do século passado que se provaram falidos, não deixou de reconhecer a importância do Estado e reservar-lhe a possibilidade de atuar como agente de mercado em situações específicas.

Em seguida, debruçamo-nos sobre o conceito de interesse público, ou coletivo, que representa o fundamento fulcral de qualquer atuação do Estado, inclusive e especialmente no domínio econômico.

\footnotetext{
${ }^{36}$ MOREIRA NETO, Diogo de Figueiredo. Curso de Direito Administrativo, 15ª ed., Rio de Janeiro: Forense, 2011, p. 12.

${ }^{37}$ Daniel Sarmento, Gustavo Binenbojm, Humberto Ávila e Marçal Justel Filho são alguns dos doutrinadores expoentes na corrente que questiona a existência do princípio no ordenamento brasileiro.

${ }^{38}$ JUSTEN FILHO, Marçal. Op. cit., p. 813.

39 BARROSO, Luís Roberto. A Ordem Econômica Constitucional e os Limites à Atuação do Estatal no Controle de Preços. Op. cit., p. 56.
} 
Cabe-nos agora o estudo dos meios que o Estado contemporâneo tem em suas mãos para por em prática tal intervenção. É nessa gaveta do direito administrativo que está incluído o instituto da sociedade de economia mista.

Como costumeiro nas classificações jurídicas, há certa divergência doutrinária em relação às denominações de cada uma das modalidades de intervenção. Entretanto, inobstante a discordância terminológica, é destacável a considerável concordância na identificação dos mecanismos em meio a uma pluralidade de níveis de intervenção estatal resultante de diferenças políticas e ideológicas ao redor do mundo.

Sem perder tempo com a roupagem e concentrando os esforços no conteúdo dos mecanismos, acompanhamos a classificação tríplice do professor Luis Roberto Barroso, que engloba todas as demais de forma simples, porém eficiente: (a) fomento, (b) disciplina e (c) atuação direta.

\subsubsection{Fomento}

O fomento é a atividade administrativa através da qual a Administração Pública, por meios de benefícios diferenciados, busca estimular condutas comissivas ou omissivas dos agentes econômicos que sejam desejáveis, ou desestimular aquelas que sejam indesejáveis ${ }^{40}$.

Trata-se de um mecanismo que visa manter a autonomia dos agentes na realização de suas escolhas, incentivando-as de forma não coercitiva, isto é, sem qualificar as condutas objetivadas como obrigatórias ou proibidas.

São exemplos comuns de medidas de fomento utilizadas pelo governo brasileiro os incentivos fiscais, os subsídios e os financiamentos. Por meio da concessão desses benefícios, a Administração Pública intenciona que os agentes econômicos realizem uma conduta que não seria realizada caso não houvesse o prêmio.

\footnotetext{
${ }^{40}$ JUSTEN FILHO, Marçal. Op. cit., p. 677-678; BARROSO, Luís Roberto. A Ordem Econômica Constitucional e os Limites à Atuação do Estatal no Controle de Preços. Op. cit., p. 59.
} 
A lógica é que tais condutas não são naturalmente vantajosas para o particular e não seriam praticadas sem o benefício concedido pelo Estado. É o caso, por exemplo, da instalação de uma fábrica de automóveis na região norte brasileira. Embora distante do principal mercado consumidor, localizado ao sul do país, a geração de empregos e o desenvolvimento de uma região mais pobre vai ao encontro do interesse público e atende direitos fundamentais protegidos pelo ordenamento jurídico constitucional. Em nome desses interesses, o governo poderia conceder isenções fiscais para que a instalação da fábrica na região nordeste se torne economicamente viável para a montadora; essa, por sua vez, decidiria onde instalar a fábrica, a seu exclusivo critério, sem que uma recusa à instalação no nordeste ensejasse qualquer penalidade.

Fica claro assim, que o fomento não é o campo das medidas cogentes, típicas da atividade de disciplina. O mecanismo abarca somente a direção de condutas que ou não são passíveis de coerção, sob pena de agressão a outros direitos fundamentais, ou não são tão relevantes para a defesa do interesse público, caso em que, por atenção ao princípio da indisponibilidade, a Administração Pública não poderia se contentar somente em incentivá-las.

Vale mencionar que o instrumento vive atualmente um período de destaque na conjuntura nacional de ajuste econômico - baseado essencialmente na elevação da arrecadação e na contenção dos gastos do governo - e constantes críticas a um governo que teria criado campeões nacionais $^{41}$.

Como bem colocou José Vicente Santos de Mendonça, o fomento é indubitavelmente um importante instrumento de apoio ao desenvolvimento econômico em direções socialmente desejáveis, mas um desvio na sua utilização pode rapidamente transformá-lo na "enésima ajuda do Rei aos

\footnotetext{
${ }^{41}$ Denominação que vem sendo utilizada para se referir a um grupo de empresas que se tornaram gigantes de mercado por terem aproveitado diversos subsídios, financiamentos e isenções concedidos em seu favor pela Administração Pública.
} 
seus amigos $" 42$. O perigo é ainda mais real em uma sociedade que segue entrelaçada em práticas patrimonialistas e possui um Estado ainda muito distante da estrita impessoalidade na condução da coisa pública.

Sem dúvida, esse é o principal problema dessa modalidade de intervenção: o risco da ausência do cuidado necessário na adoção dos critérios, bem como a transparência de sua comunicação ao mercado, violarem a livre-concorrência, a impessoalidade e a isonomia entre agentes econômicos inseridos em um regime de competição supostamente equilibrado.

Em solo pátrio, o Banco Nacional do Desenvolvimento Econômico e Social - BNDES é talvez o maior símbolo da atividade de fomento. Sem adentrar à discussão sobre os moldes da sua utilização atual, o banco ocupa hoje uma posição crucial na estrutura da economia brasileira e é extremamente importante para a continuidade e o desenvolvimento de diversos setores. No setor de infraestrutura, por exemplo, não veríamos projetos importantes seguirem em frente (muito por conta das tarifas incompatíveis adotadas nas concessões, mas isso é tema para outra discussão) sem os empréstimos a juros abaixo da taxa de mercado feitos pelo banco. No mesmo sentido, diversas micro e pequenas empresas não veriam seus negócios saírem do papel sem os financiamentos subsidiados.

Todavia, apontando apenas matéria pacífica e deixando de lado a discussão se esses negócios e projetos não sustentáveis a taxas de mercado deveriam ser de fato subsidiados e implementados, é indiscutível que efeitos positivos exigem um ajuste fino e difícil dos benefícios concedidos, o qual nem sempre é atingido.

O fomentador estatal, além de adotar critérios rígidos, bem definidos e claramente comunicados para a concessão dos empréstimos beneficentes, deve afinar a duração e a taxa de juros para evitar que um suposto estímulo

\footnotetext{
${ }^{42}$ MENDONÇA, José Vicente Santos de. Uma teoria do Fomento Público: Critérios em Prol de um Fomento Público Democrática, Eficiente e Não-Paternalista. Revista de Direito da Procuradoria Geral, v. 65, Rio de Janeiro, 2010, p. 210.
} 
se torne um empecilho ao desenvolvimento econômico ao favorecer demasiadamente um determinado setor ou player.

Isso porque a concessão de financiamento a taxas extremamente favorecidas ou com prazos de duração excessivamente extensos tende a levar à completa desregulação do mercado, essencialmente fundando no regime de livre competição. O raciocínio é simples: um empreendimento privado que levante crédito nas condições de mercado não será capaz de competir em regime de preços com um adversário que levante crédito em condições melhores mediante auxílio estatal; por consequência, o empreendedor menos favorecido não irá perseguir ou sequer adentrar na atividade econômica. Reduz-se assim a competição e consequentemente o crescimento econômico.

A despeito dos riscos contra a livre iniciativa, a impessoalidade e a isonomia entre os agentes econômicos, sejam eles resultantes de má-fé ou erro na calibragem dos benefícios, o fomento é um mecanismo competente para incentivar o desenvolvimento de algumas atividades, sendo difícil imaginar a sua exclusão do rol de mecanismos disponíveis à Administração Pública. Até mesmo porque, como se verá adiante, é a modalidade que, em tese, menos ofende a autonomia privada e a liberdade de escolha a ela subjacente.

\subsubsection{Disciplina}

Diametralmente oposta à atividade de fomento no que se refere à coercitividade está o mecanismo da disciplina. Essa atividade consiste e pode ser subdivida (i) na regulação das condutas dos agentes econômicos, de modo permanente e sistemático ${ }^{43}$; (ii) na fiscalização da prática de tais condutas; (iii) e na aplicação das devidas sanções ao infrator.

\footnotetext{
${ }^{43}$ JUSTEN FILHO, Marçal. Op. cit., p. 637.
} 
Aqui o Estado age como agente regulador e fiscalizador, duas facetas privilegiadas pelo pensamento político-econômico contemporâneo em desfavor da atuação direta como agente econômico ${ }^{44}$.

Diferentemente do que ocorre com os instrumentos de fomento, onde as condutas dos particulares são meramente incentivadas, a disciplina impõe comportamentos compulsórios aos agentes econômicos a partir da edição de normas cogentes. Opera-se, portanto, uma retração muito maior do espaço da autonomia privada e da livre iniciativa, visto que senão elimina, limita substancialmente a liberdade de escolha do particular com relação a determinadas questões ${ }^{45}$.

Como toda atividade estatal, em especial aquelas limitadoras de direitos fundamentais, a regulação e a fiscalização da ordem econômica também não podem ser exercidas de forma absolutamente discricionária pelo Poder Público. Pelo contrário, a intervenção disciplinadora deve respeitar rígidas limitações ao derrogar determinado princípio em privilégio de outro.

$\mathrm{O}$ atual modelo estatal brasileiro superou o Estado Liberal, onde qualquer atuação estatal era reprimida, mas colocou também no passado o Estado interventor, em que a atuação direta era o modelo preferido. A Constituição Federal de 1988 configurou um Estado preponderantemente regulador e fiscalizador da iniciativa privada, já não mais compreendida como autossuficiente e ilimitável, mas novamente alçada ao cargo de principal agente econômico.

Firmaram-se como pilares do novo compromisso constitucional os princípios da livre iniciativa, do direito à propriedade privada, da livre concorrência e da liberdade de contratação, sem deixar, contudo, de “temperá-los" com os princípios corretivos ${ }^{46}$ citados anteriormente.

\footnotetext{
44 “A regulação consiste na opção preferencial do Estado pela intervenção indireta, puramente normativa. Revela a concepção de que a solução política mais adequada para obter os fins buscados consiste não no exercício direto e imediato pelo Estado de todas as atividades de interesse público." (Ibid., p. 639)

${ }^{45}$ BARROSO, Luís Roberto. A Ordem Econômica Constitucional e os Limites à Atuação do Estatal no Controle de Preços. Op. cit., p. 60.

${ }^{46}$ EIZIRIK, Nelson. Op. cit., p. 290.
} 
A regulação pretende exatamente conduzir a ordem econômica de forma a garantir o equilíbrio entre esses princípios. Nesse sentido, só pode ser concebida caso não ofenda os referidos princípios-pilares em seu núcleo fundamental e tenha como objetivo o estabelecimento do equilíbrio através da promoção dos princípios de funcionamento ${ }^{47}$ ou dos fundamentos da ordem econômica constantes do art. 170 da Constituição Federal de $1988^{48}$; quais sejam, a valorização do trabalho humano, a função social da propriedade, a defesa do consumidor, a defesa do meio ambiente, a soberania nacional, e as próprias livre iniciativa, livre concorrência e direito à propriedade privada. Em todo e qualquer caso, a validade da intervenção disciplinadora estará sujeita ainda à aderência ao princípio da razoabilidade, que exige prova de adequação, necessidade e proporcionalidade da medida ${ }^{49}$.

Resta claro que a disciplina não pretende e nem pode substituir o mercado em seu papel na ordem econômica, porém se mostra de extrema

\footnotetext{
${ }^{47}$ Segundo classificação de Luis Roberto BARROSO, é possível classificar os princípios da ordem econômica descritos no art. 170 da Constituição Federal em "dois grandes grupos, conforme se trate de princípios de funcionamento da ordem econômica e de princípios-fins. Em linhas gerais, os princípios de funcionamento estabelecem os parâmetros de convivência básicos que os agentes da ordem econômica deverão observar. Os princípios fins, por sua vez, descrevem realidades materiais que o constituinte deseja sejam alcançadas." Ainda segundo o autor, seriam princípios de funcionamento aqueles descritos nos incisos I a VI do art. $170 \mathrm{da} C \mathrm{CF} / 88$ e princípios-fins aqueles constantes dos incisos VII a IX do mesmo dispositivo. (BARROSO, Luís Roberto. A Ordem Econômica Constitucional e os Limites à Atuação do Estatal no Controle de Preços. Op. cit., p. 49).

${ }^{48}$ Constituição Federal de 1988, art. 170: "A ordem econômica, fundada na valorização do trabalho humano e na livre iniciativa, tem por fim assegurar a todos existência digna, conforme os ditames da justiça social, observados os seguintes princípios: I - soberania nacional; II propriedade privada; III - função social da propriedade; IV - livre concorrência; V - defesa do consumidor; VI - defesa do meio ambiente, inclusive mediante tratamento diferenciado conforme o impacto ambiental dos produtos e serviços e de seus processos de elaboração e prestação; VII redução das desigualdades regionais e sociais; VIII - busca do pleno emprego; IX - tratamento favorecido para as empresas de pequeno porte constituídas sob as leis brasileiras e que tenham sua sede e administração no País. Parágrafo único. É assegurado a todos o livre exercício de qualquer atividade econômica, independentemente de autorização de órgãos públicos, salvo nos casos previstos em lei."

49 "Em resumo sumário, o princípio da razoabilidade permite ao Judiciário invalidar os atos administrativos quando: a) não haja adequação entre o fim perseguido e o instrumento empregado (adequação); b) a medida não seja exigível ou necessária, havendo meio alternativo menos gravoso para chegar ao mesmo resultado (necessidade/vedação de excessos); c) os custos superem os benefícios, ou seja, o que se perde com a medida é de maior relevo do que aquilo que se ganha (proporcionalidade em sentido estrito)." (BARROSO, Luís Roberto. Curso de Direito Constitucional Contemporâneo: os conceitos fundamentais e a construção do novo modelo. Op. cit., p 328). Sobre o tema, ver também: BANDEIRA DE MELLO, Celso Antônio. Op. cit., p. 111-112.
} 
importância em um Estado que pretende ser a melhor fusão possível dos valores mais importantes do Estado Liberal e do Estado Social. Em conjunto com o mecanismo de fomento, é responsável por conciliar princípios à primeira vista absolutamente incompatíveis como esses que regem o funcionamento da ordem econômica.

São inúmeras as normas disciplinadoras espalhadas pelo ordenamento em formas diferentes. Um exemplo famoso é o Código de Defesa do Consumidor (Lei 8.078/90) que, além de carregar na própria denominação o vínculo direto com um dos princípios de funcionamento da ordem econômica, tem origem constitucional direta, estando sua edição prevista no art. 5, XXII da Constituição Federal de 1988. Outras normas disciplinadoras da atuação privada, vastamente encontradas em regulamentos como portarias ministeriais, decretos executivos e resoluções de órgãos vinculados à Administração Pública, tem origem na legislação infraconstitucional e até na jurisprudência do Poder Judiciário ${ }^{50}$.

Para encerrar o ponto, vale aproveitar a menção aos regulamentos para destacar a ascensão das agências reguladoras no cenário nacional, notadamente após os movimentos de privatização do fim do século XX e início do século XXI.

As agências reguladoras são autarquias responsáveis por editar normas de condicionamento e coordenação da iniciativa privada (e também do Estado, quando este atuar diretamente) em alguns setores da economia, bem como fiscalizar o seu cumprimento e sancionar sua infração. Criada sob um regime especial e diferenciado que lhe garante a máxima independência possível, trata-se do instrumento que simboliza o Estado regulador e a descentralização da Administração Pública, a partir da criação

\footnotetext{
${ }^{50}$ Marçal Justen Filho afirma que "a regulação econômico-social é um dos tipos de atividade estatal, que se traduz no desempenho tanto de função administrativa como legislativa, jurisdicional e de controle. Portanto, seria um equivoco imaginar que a regulação corresponde apenas ao exercício da atividade administrativa. Ademais disso, a regulação econômico-social compreende atuações provenientes das diversas órbitas federativas". Como exemplo que confirma a afirmação, o autor cita a possibilidade de tarifas de serviços públicos serem questionados perante o Poder Judiciário, sendo comumente fixadas por provimento jurisdicional. (JUSTEN FILHO, Marçal. Op. cit., p. 638).
} 
de órgãos com caráter cada vez mais técnicos, dotados de autonomia funcional e protegidos da ingerência política ${ }^{51}$.

\subsubsection{Atuação Direta}

Chegamos, enfim, à atuação direta do Estado no domínio econômico. A modalidade de intervenção mais polêmica e controversa é também a mais relevante para o presente trabalho.

No caminho até aqui concluímos ser "fora de dúvida que os particulares são os principais atores da ordem econômica brasileira" ${ }^{\text {. }}$. Nossa constituição afirmou a opção pelo regime capitalista e alçou a livre iniciativa e a livre concorrência às categorias de fundamento e princípio de funcionamento $^{53}$ da ordem econômica, respectivamente ${ }^{54}$.

Porém, fixadas essas bases, o legislador constituinte quis, paralela e excepcionalmente, reservar ao Estado a possibilidade de atuar na ordem econômica de forma direta, assumindo, ele próprio, o papel de produtor ou prestador de bens ou serviços ${ }^{55}$.

Ao contrário do que ocorre nas atividades de fomento e disciplina, o Estado aqui não incentiva ou determina que condutas desejáveis ou indesejáveis sejam exercidas ou não pelos particulares, mas assume ele próprio a sua execução, operando na qualidade de agente econômico.

A modalidade assume duas apresentações distintas: a prestação de serviços públicos e a exploração de atividades econômicas. A diferenciação é estabelecida constitucionalmente e são diversas as regras às quais cada uma delas está subordinada.

\footnotetext{
51 Para um completo estudo sobre agências reguladoras: ARAGÃO, Alexandre Santos de. Agências Reguladoras e a Evolução do Direito Administrativo Econômico, $2^{\mathrm{a}}$ Ed., Rio de Janeiro: Forense, 2006.

52 BARROSO, Luís Roberto. A Ordem Econômica Constitucional e os Limites à Atuação do Estatal no Controle de Preços. Op. cit., p. 56.

${ }^{53}$ Constituição Federal de 1988, art. 170, caput e inciso IV.

${ }^{54}$ JUSTEN FILHO, Marçal. Op. cit., p. 807.

55 BARROSO, Luís Roberto. A Ordem Econômica Constitucional e os Limites à Atuação do Estatal no Controle de Preços. Op. cit., p. 58.
} 
Sobre a primeira, vale pedir licença para transcrever integralmente a definição de Marçal Justen Filho: "Serviço público é uma atividade pública administrativa de satisfação concreta de necessidades individuais ou transindividuais, materiais ou imateriais, vinculadas diretamente a um direito fundamental, insuscetíveis de satisfação adequada mediante os mecanismos da livre iniciativa privada, destinada a pessoas indeterminadas, qualificada legislativamente e executada sob regime de direito público. ",56

Vemos assim, dois critérios relevantes e que merecem destaque na caracterização de um serviço público: (i) atividade vinculada à garantia de um direito fundamental; e (ii) inadequação dos mecanismos da livre iniciativa para sua satisfação. Dessa natureza, decorre a titularidade atribuída ao Estado e a consequente submissão ao regime de direito público $^{57}$.

A rigidez na observação desses critérios é fundamental. A exploração de titularidade do Estado e o regime de monopólio, em princípio, fazem com que os serviços públicos sejam submetidos a uma aplicação diferenciada dos princípios da livre iniciativa e livre concorrência. $^{58}$ Permitir a classificação indiscriminada de qualquer atividade como serviço público seria reconhecer a possibilidade de sufocar certos pilares do regime capitalista muito além do que desejou o constituinte $^{59}$.

\footnotetext{
${ }_{57}^{56}$ JUSTEN FILHO, Marçal. Op. cit., p. 687.

57 "O Estado também pode atuar no domínio econômico mediante a prestação de serviços públicos. O serviço público constitui toda a atividade de oferecimento de comodidade que possa ser fruída pelos administrados, prestada diretamente pelo Estado ou outra pessoa, sob um regime de direito público. $\mathrm{O}$ traço caracterizador desse serviço é de natureza formal, consistente no regime especifico de direito público, ainda que seja prestado por particular, do qual são exemplos: (i) a estrita submissão ao princípio da legalidade; (b) a utilização de técnicas autoritárias pelo Estado, como a possibilidade de instituir obrigações mediante ato unilateral; (iii) a presunção de legitimidade e autoexecutoriedade dos atos praticados; e (iv) a necessária continuidade das atividades tidas como de interesse público.” EIZIRIK, Nelson. Op. cit., p. 288.

${ }^{58}$ Não se trata de um afastamento por completo, pois no limite do possível há concorrência entre os competidores. Veja-se, por exemplo, as concessões de serviços em que sagram-se vencedores aqueles que oferecerem, livremente, o melhor preço de outorga, a melhor tarifa de concessão, ou qualquer outra regra definida pela edital de licitação.

59 "A Constituição consagrou o regime capitalista, fundado nos princípios da livre iniciativa e da livre concorrência. Os serviços públicos são excluídos do âmbito desses princípios. Se o Estado
} 
Maiores polêmicas, entretanto, circundam a atuação direta do Estado no exercício de atividade econômica em sentido estrito. Assim como a prestação de serviços públicos, a faceta de Estado-empresário também tem natureza excepcionalíssima e, por representar um exclusão do princípio basilar da livre-iniciativa ${ }^{60}$, só pode ser posta em prática nos seguintes casos previstos no art. 173 da Constituição Federal de 1988: (a) nos casos previstos a priori na própria Constituição; (b) nas situações necessárias aos imperativos da segurança nacional; ou (c) se houver relevante interesse coletivo. Trata-se de uma suplementariedade restrita, no termo utilizado por Nelson Eirizik.

Diferentemente dos serviços públicos, uma espécie do gênero atividade econômica, a atividade econômica em sentido estrito é submetida e executada pelo Estado em regime de direito privado, sendo-lhe integralmente aplicáveis os princípios da livre concorrência e da livre iniciativa. A Constituição exige a igualdade do Estado ao competir com os agentes privados, proibindo a atuação da Administração Pública direta e determinando a constituição de empresas públicas ou sociedades de economia mistas, sem qualquer benefício ou privilégio, de acordo com os $\S 1^{\circ}$ e $\S 2^{\circ}$ do art. $173^{61}$.

As atividades encaixadas no primeiro caso são aquelas descritas no artigo 177 da Constituição, as quais, em virtude de sua relevância política e econômica, o legislador constituinte decidiu aplicar um regime diferenciado

pudesse assumir o desempenho direto das atividades econômicas propriamente ditas e a elas aplicar privilégios e benefícios, estaria destruída a distinção básica. Então, todas as atividades poderiam ser transformadas em serviço público, inclusive aquelas destituídas de cunho essencial. Assim não é, uma vez que não se admite que o Estado qualifique como serviço público atividade não vinculada diretamente aos direitos fundamentais.” (JUSTEN FILHO, Marçal. Op. cit., p. 807)

${ }^{60}$ BARROSO, Luís Roberto. A Ordem Econômica Constitucional e os Limites à Atuação do Estatal no Controle de Preços. Op. cit., p. 58.

${ }^{61}$ Constituição Federal de 1988, art. 173: "Ressalvados os casos previstos nesta Constituição, a exploração direta de atividade econômica pelo Estado só será permitida quando necessária aos imperativos da segurança nacional ou a relevante interesse coletivo, conforme definidos em lei. $\S 1^{\circ}$ A lei estabelecerá o estatuto jurídico da empresa pública, da sociedade de economia mista e de suas subsidiárias que explorem atividade econômica de produção ou comercialização de bens ou de prestação de serviços, dispondo sobre: [...] II - a sujeição ao regime jurídico próprio das empresas privadas, inclusive quanto aos direitos e obrigações civis, comerciais, trabalhistas e tributários; [...] $\S 2^{\circ}$ - As empresas públicas e as sociedades de economia mista não poderão gozar de privilégios fiscais não extensivos às do setor privado." (grifos nossos) 
e mais eventual de livre iniciativa e livre concorrência, submetendo-os submeter ao regime de monopólio ${ }^{62}$. Trata-se aqui de uma decisão de cunho político que visa garantir a soberania nacional ou outros valores essenciais através do estabelecimento de monopólios estatais ${ }^{63}$.

Quanto ao segundo caso, sem embargo da discussão em torno do conceito exato de segurança nacional e da perigosa utilização genérica do termo $^{64}$ - como ocorreu no período não democrático -, é inquestionável a ressalva constitucional para excepcionar a atuação econômica direta do Estado nos casos em que esteja em jogo a defesa da soberania e dos valores fundamentais da Nação ${ }^{65}$.

O último caso também envolve um conceito jurídico indeterminado tal como a segurança nacional. Conforme exposto no capítulo anterior, o interesse coletivo - tratado como sinônimo do interesse público - consiste, em termos gerais, no interesse supraindividual, de toda a sociedade. Não à toa, é a válvula de escape mais costumeiramente utilizada para justificar as

\footnotetext{
${ }^{62}$ Embora a Constituição tenha ampliado o elenco de setores de monopólios do Estado, ela também impossibilitou a criação de novos monopólios estatais, salvo através de emenda constitucional. São atribuídos cinco monopólios à União, conforme artigo 177 da Constituição: (i) pesquisa e lavra de jazidas de petróleo e gás natural e outros hidrocarbonetos fluído; (ii) refinação de petróleo nacional ou estrangeiro; (iii) importação e exportação dos produtos e derivados do petróleo; (iv) transporte marítimo ou por meio de conduto do petróleo bruto, seus derivados e gás natural de qualquer origem; e (v) pesquisa, lavra, enriquecimento, reprocessamento, industrialização e comércio de minério e minerais nucleares e seus derivados. O monopólio do petróleo e seus derivados foi flexibilizado com a Emenda Constitucional $\mathrm{n}^{\circ}$ 09/1995, regulamentada pela Lei $\mathrm{n}^{\circ}$ 9.478/1997, que autorizou a Petróleo Brasileiro S.A. - Petrobras a formar consórcios com empresas nacionais e internacionais. Nesse sentido, veja-se: EIZIRIK, Nelson. Op. cit., p. 289.

${ }^{63}$ Sobre a definição de monopólio e a distinção entre monopólios estatais e monopólios privados, vale transcrever o magistério de Carvalho Filho: "Monopólio significa a exploração exclusiva de um negócio, em decorrência da concessão de um privilégio. O monopólio privado é absolutamente vedada pela Constituição, porque permite a dominação do mercado e a eliminação da concorrência, fatores que espelham abuso do poder econômico. A empresa monopolista a curto prazo tem condições de obter lucro máximo e não necessita se ajustar aos preços de mercado. Não é difícil observar que tal situação é total incompatível com o sistema adotado na Constituição, cabendo no caso a presença do Estado-Regulador. O mesmo não se passa com o monopólio estatal, isto é, aquele que é exercido pelo Estado ou por delegados expressamente autorizados a tanto. A diferença, porém, é flagrante. Enquanto o monopólio privado tem por escopo o aumento de lucros e o interesse privado, o monopólio estatal visa sempre à proteção do interesse público." (CARVALHO FILHO, José dos Santos. Op. cit., p. 924)

${ }^{64}$ "O conceito 'segurança nacional' não é indefinido nem vago, nem aberto àquele discricionarismo do Presidente ou do Congresso. 'Segurança nacional' envolve toda a matéria pertinente à defesa da integridade do território, independência, sobrevivência e paz do país, suas instituições e valores materiais ou morais contra ameaças externas e internas, seja elas atuais e imediatas ou ainda em estado potencial próximo ou remoto" (STJ, RE n. 62.730, Rel. Min. Aliomar Baleeiro, Brasília, Julg. 23 ago. 1967. DJ, 20 dez. 1967)

${ }^{65}$ JUSTEN FILHO, Marçal. Op. cit., p. 812.
} 
mais diversas decisões políticas, tornando complexo o controle das condutas da Administração Pública nessa esfera.

Tal expediente ocorre a despeito da exigência constitucional de uma qualificação adicional do interesse coletivo que enseja a atuação direta do Estado como agente econômico, qual seja a sua "relevância". Constata-se assim o caráter excepcionalíssimo que a vontade constitucional decidiu imprimir à situação, ao não só exigir um interesse coletivo para motivar a atuação, mas um interesse coletivo significativo e emergencial.

Essa excepcionalidade não é ocasional e se coaduna com a orientação geral capitalista da ordem econômico, fundada na livre iniciativa privada, e ao mesmo tempo com o reconhecimento constitucional de determinadas garantias aos cidadãos que, em casos específicos, poderão ter o Estado como provedor.

A precaução na construção do limite se justifica. Como se verá adiante, seja em regime de monopólio ou de competição, a atuação direta do Estado representa uma supressão considerável das liberdades individuais e impõe dificuldades na manutenção da isonomia com os particulares, na conciliação do lucro com a consecução do interesse público, na preservação do mercado competitivo, entre outras questões resultantes das idiossincrasias da modalidade.

Com essas questões em mente, passamos ao estudo das sociedades de economia mista como um dos instrumentos disponíveis ao Estado para atuar diretamente no domínio econômico. 


\section{SEGUNDA PARTE \\ AS SOCIEDADES DE ECONOMIA MISTA E AS SUAS \\ PECULIARIDADES}

\subsection{A origem das sociedades de economia mista}

Sem embargo de suas origens estáveis serem identificadas em época mais recente, o surgimento das sociedades de economia mista remonta ao próprio embrião das sociedades anônimas, corporificado pela maioria dos historiadores do direito nas grandes companhias de comércio - Companhias das Índias - criadas na Holanda no início do século XVII ${ }^{66}$.

Assim sendo, antes de adentrarmos diretamente no estudo das sociedades de economia mista, analisaremos as raízes da sociedade anônima para, em seguida, aventar sobre a participação do erário público ao lado de recursos privados na formação do capital dessas sociedades.

\subsubsection{A origem simultânea das sociedades anônimas e das sociedades de economia mista}

No século XVI, a ascensão dos Estados Modernos sob o poder absolutista, centralizado nas mãos do Rei, fez florescerem rivalidades entre as recém-surgidas nações européias.

O endurecimento dessa competição passou a exigir fortes investimentos nas atividades mercantilistas marcadas pela expansão ultramarina das fronteiras nacionais. O domínio colonial de regiões fora do continente europeu era o que lhes garantia o acesso à matéria-prima e criava mercado para escoamento dos seus produtos manufaturados. Ao mesmo tempo, essa exploração e a proteção do monopólio colonial também

\footnotetext{
${ }^{66}$ LIMA, Paulo B. de Araújo. Sociedade de Economia Mista e a Lei das S.A., Rio de Janeiro: IBMEC, 1980, p. 19; VENÂ̂NCIO FILHO, Alberto. Sociedades de Economia Mista. In: LAMY FILHO, Alfredo; PEDREIRA, José Luiz Bulhões (Coord.). Direito das Companhias, vol. 2, $1^{\text {a }}$ ed.. Rio de Janeiro: Forense, 2009, p. 1908.
} 
demandavam a aplicação de capital cada vez maior no reforço dos instrumentos bélicos.

Foi nesse contexto, de carência de recursos públicos para exercer a política estatal de expansão colonial e exploração de territórios além mar, que surgiram as primeiras formas de sociedade anônima, as quais tinham por escopo o enriquecimento da coroa, a segurança e a proteção do Estado $^{67}$.

Assim, apesar da discussão em torno da sua origem ${ }^{68}$, a maior parte da doutrina inclina-se a ver na Companhia das Índias Orientais, criada na Holanda em 1602, a instituição que primeiro apresentou contornos próximos daqueles que têm hoje as sociedades anônimas.

Criada por ato do governo holandês, a Companhia tinha seu capital dividido em parcelas de valores idênticos, representados por títulos denominados ações. Quem quisesse partilhar dos lucros advindos da empresa colonial deveria adquirir essas ações, negociadas na Bolsa de Amsterdã. A responsabilidade do adquirente ou subscritor limitava-se ao valor das ações, assim como acontece atualmente.

Ajustada às práticas econômicas mercantilistas que ganhavam corpo naquela época, a reunião de capitais privados e públicos com a chancela real justificava-se na necessidade da coroa holandesa de viabilizar a expansão ultramarina e fazer frente ao poderio espanhol e português nos mares. A companhia, por sua vez, consistia no instrumento capaz de proporcionar essa reunião essencial à formação de grandes empreendimentos, tal como as grandes navegações.

\footnotetext{
${ }^{67}$ SANTOS, Theophilo de Azeredo. As Sociedades de Economia Mista no Direito Brasileiro: Prática, Jurisprudência, Legislação. Rio de Janeiro: Forense, 1959, p. 8.

${ }^{68}$ Há quem enxergue a Casa de San Giorgio (mais tarde, Banco de San Giorgio), e não as Companhias das Índias, como a primeira expressão do que viriam a ser as sociedades anônimas. Fundada em Gênova em 1407, tratava de uma estrutura criada pelos credores da República de Gênova para administração de empréstimos cuja garantia era a arrecadação de certos impostos. Posteriormente, a instituição se tornou um banco, que operou até 1799. Seguimos, contudo, a corrente majoritária que vê nessa estrutura algo mais próximo das associações modernas de debenturistas. Nesse sentido, veja-se: REQUIÃO, Rubens. Curso de Direito Comercial, v. 2, $18^{\mathrm{a}}$ ed., São Paulo: Saraiva, 1992, p. 3.
} 
Dezenove anos mais tarde e bem sucedida a primeira investida, foi criada em 1621 a Companhia das Índias Ocidentais, dessa vez para a exploração comercial da América. Novamente o Estado holandês participou da formação do capital, comprometendo-se a partilhar lucros e prejuízos nas mesmas condições dos demais participantes particulares. À sociedade foram concedidos poderes para avençar pactos internacionais e nomear governadores e funcionários da justiça, atuando, portanto, como um verdadeiro ente administrativo descentralizado da Coroa holandesa nas províncias das colônias exploradas.

Indubitável, assim, que a participação do Estado ao lado de particulares no capital de sociedades anônimas não é novidade na história. Muito pelo contrário esse caráter publicístico inicialmente atribuído às sociedades anônimas permaneceria evidente por mais dois séculos. Mesmo após o acolhimento no sistema societário pelo Código de Comércio Francês de 1807, a constituição de sociedades anônimas seguiu demandando a autorização do Estado, que além de aprovar os atos constitutivos, poderia inserir dispositivos em seus estatutos como melhor lhe conviesse ${ }^{69}$.

Somente com a consolidação do Estado Liberal e a disseminação da doutrina do laissez faire, que pregava a intervenção estatal mínima na ordem econômica, é que a autorização começou a deixar de ser necessária: produto da separação rígida entre Estado e economia que se consolidou no período.

A partir daí, viveu-se um longo de tempo de enfraquecimento da presença do capital público em sociedades empresárias, já que a atividade econômica era vista como uma função a ser desempenhada exclusivamente por agentes privados em regime de livre iniciativa e competitividade.

O ressurgimento da ideia de associação entre capital público e privado se daria mais tarde, com a crise do modelo de concessões -

\footnotetext{
${ }^{69}$ Conforme o art. 37 do Código Comercial Francês de 1807 (Code): "La société anonyme ne peut exister qu'avec l'autorisation du Gouvernement, et avec son approbation pour l'acte qui la constitue; cette approbation doit être donnée dans la forme prescite pour les règlements d'administration publique".
} 
inicialmente adotado para a prestação de serviços públicos essenciais - em meio ao enfraquecimento dos ideais liberais e ao fortalecimento do Estado Social.

Até o final do século XIX e início do século XX, a prestação de diversos serviços públicos estava nas mãos dos empresários privados, em regime de concessão ${ }^{70}$. Oriundos das grandes descobertas do século, como a telefonia, a geração de energia elétrica, o gás combustível, dentre outras, a exploração de tais serviços exigia um investimento enorme e oferecia margens pequenas de lucro. Essas variáveis tornavam necessário que o Poder Público concedente garantisse ao particular concessionário o monopólio da atividade por um longo período de tempo, capaz de assegurar o retorno exigido mesmo com a cobrança de tarifas acessíveis para a população $^{71}$.

Ocorre que as grandes flutuações econômicas, típicas do século XIX, exerceram forte pressão sob o regime de preços que sustentava as concessões. Na virada do século, a equação econômica dos contratos estava deteriorada e a demora do poder concedente em ajustá-las repercutiu rápida e negativamente no desempenho dos serviços.

Foi nesse contexto que ao Estado incumbiu assumir as funções desempenhadas pelos concessionários e, dado ao fluxo de atividades industriais e comerciais típicas, que não poderiam obedecer às estruturas burocráticas peculiares à atuação estatal, cogitou-se das sociedades de economia mista para tanto.

O Estado voltou então a fazer parte do capital das sociedades anônimas no intuito de assumir sua gestão e evitar a descontinuidade dos serviços e o prejuízo ao interesse público.

Paralelamente à problemática das concessões, ganhou espaço o Estado Social, estampado na política do Welfare State e empenhado em intervir na economia para suprir as deficiências da iniciativa privada. Havia

\footnotetext{
${ }^{70}$ EIZIRIK, Nelson. Op. cit., p. 284.

${ }^{71}$ LIMA, Paulo B. de Araújo. Op. cit., p. 22.
} 
aí mais um impulso para que o Estado participasse do capital e assumisse a gestão de companhias responsáveis pelo exercício de atividades econômicas diversas.

Esse segundo momento da associação de capitais públicos e privados diferencia-se do primeiro especialmente por não visar apenas o lucro, mas por ter como causa determinante a atenção ao interesse público. As sociedades de economia mista passam de um modo de enriquecimento da Coroa a um instrumento de atuação da Administração Pública, a qual, como já visto, dirige-se única e exclusivamente à promoção e proteção do interesse público.

\subsection{As sociedades de economia mista no Brasil}

A primeira sociedade de economia mista do país foi o Banco do Brasil. Criado inicialmente em outubro de 1808, mediante alvará do Príncipe Regente Dom João, o banco nasceu sob a forma de sociedade privada por ações, tendo sido convertido em sociedade de economia mista somente em 1812, quando através de Carta Régia a Coroa se tornou seu principal acionista. Tal status é mantido até hoje e o Estado brasileiro segue como principal acionista do segundo maior banco do país.

Inobstante o primeiro caso no século XIX, foi no século XX que o instrumento ganhou relevância em solo pátrio. Sob os ditames das Constituições de 1934 e 1937, influenciadas pela política do welfare state

americano, foi no Governo Vargas que se verificou a emergência da atuação empresarial do Estado brasileiro, intensificada posteriormente durante o governo militar.

O regime varguista tinha como foco principal a substituição das importações por produtos produzidos internamente, mediante o estímulo à industrialização nacional.

Nesse período, a carência de recursos privados para realização dos vultosos investimentos necessários somada às ideias que dominavam o 
cenário político-econômico internacional, abriram espaço para o que o Estado brasileiro assumisse papel de destaque na condução da economia e fosse erguido à posição de agente responsável por estimular o desenvolvimento econômico.

Ao pacote deve-se ainda acrescentar a preocupação com a segurança nacional, conservada com a manutenção de atividades estratégicas sob controle do Estado, e as falhas regulatórias em variados setores da economia que tornavam sua exploração pouco atraentes aos olhos do investidor privado ${ }^{72}$.

Esses foram os impulsos para a multiplicação de empresas estatais, em geral sob a forma de sociedade de economista mista, nas quais a União não só participava do capital, mas conduzia e direcionava as atividades, sob a justificativa de atender ao interesse público e geral $^{73}$.

Surgiram o Instituto de Reeseguros do Brasil, em 1939; a Companhia Siderúrgica Nacional - CSN, em 1941; a Companhia do Vale do Rio Doce, em 1942; a Companhia Hidrelétrica do São Francisco, em 1945; a Fábrica Nacional de Motores, em 1946; o Banco do Nordeste do Brasil, em 1952; a Petrobras, em 1953; a Eletrobrás, em 1962; exemplos que revelam o propósito do Governo Federal de acelerar a instalação de indústria de base, alicerçadas em matéria-prima nacional.

O modelo de administração culminou no Decreto $n^{\circ}$ 200/1967, que implantou a reforma administrativa federal, classificando a Administração Pública em direta e indireta e propondo uma definição clara de sociedade de economia mista. A primeira é constituída pelos ministérios e demais órgãos diretamente subordinados à Presidência da República. As sociedades

\footnotetext{
${ }^{72}$ PINHEIRO, Armando Castelar. A Experiência Brasileira de Privatização: o que vem a seguir?. Rio de Janeiro: BNDES, 2000. Disponível em $<$ http://www.bndes.gov.br/SiteBNDES/export/sites/default/bndes_pt/Galerias/Arquivos/conhecime nto/td/Td-87.pdf>. Acesso em 19 mai. 2015.

${ }^{73}$ Como bem lembra Alfredo de Almeida Paiva, a participação do Estado como simples acionista poderá ocorrer sem que se configure uma sociedade de economia mista. A característica diferenciadora dessas sociedades é justamente a sua direção pelo Estado, seja na qualidade de acionista majoritário, seja por disposição legal ou estatutária. (PAIVA, Alfredo de Almeida. As Sociedades de Economia Mista e as Empresas Públicas como Instrumentos Jurídicos a Serviço do Estado. Revista de Direito Administrativo, Rio de Janeiro, seleção histórica, 1945-1995, p. 312).
} 
de economia mista estariam incluídas na segunda categoria, ao lado de outros órgãos descentralizados, como autarquias, fundações e empresas públicas.

A definição do instituto proposta pelo artigo $5^{\circ}$, inciso III, teve sua redação posteriormente alterada pelo Decreto-Lei nº 900/1969, resultando no seguinte texto:

“Art. 5. Para os fins desta Lei, considera-se: (...) III - Sociedade de Economia Mista - a entidade dotada de personalidade jurídica de direito privado, criada por lei para a exploração de atividade econômica, sob a forma de sociedade anônima, cujas ações com direito a voto pertençam em sua maioria à União ou a entidade da Administração Indireta."

Apesar da expansão da Administração indireta ter continuado e acelerado durante o "milagre econômico" - período do regime ditatorial compreendido entre 1968 e 1973 -, o Decreto-Lei no 200 fracassou. Salvo os casos de preenchimento dos cargos públicos mediante concursos, a Administração indireta passou meteoricamente a ser utilizada como "cabide de emprego", onde políticos amigos eram nomeados em cargos de diretoria. Não fosse a barganha política suficiente para desviá-las do seu foco primordial, a utilização como instrumento de política macroeconômica fez com que as empresas estatais deixassem de lado os objetivos microeconômicos de interesse público e passassem a ser utilizadas no ajuste recessivo em um cenário de crise financeira internacional ${ }^{74}$.

A situação ruim foi agravada com a intensificação da crise e a elevação da taxa de juros, dois elementos que acertaram na veia as companhias mergulhadas em empréstimos estrangeiros utilizados para cobertura de seus caixas deficitários.

Submersos na crise do petróleo, todos esses fatores causaram séria reação no empresariado, desencorajando a base de apoio à ditadura e motivando na década de 80 os primeiros reclamos de privatização,

\footnotetext{
${ }^{74}$ PINTO JUNIOR, Mario Engler. Empresa Estatal: Função Econômica e Dilemas Societários. São Paulo: Atlas, 2010, p. 37.
} 
inspirados nos movimentos semelhantes da Inglaterra de Margaret Thatcher.

O movimento ganharia força na década subseqüente, após a promulgação da Constituição de 1988. A partir dos anos 90, iniciou-se o processo de privatização das empresas estatais, dando eficácia aos novos princípios constitucionais que determinavam a atuação residual e suplementar do Estado no domínio econômico, sobretudo na atividade empresária.

Durante o governo de Fernando Collor de Mello foi editada a Medida Provisória $n^{\circ}$ 155/1990, que institui o Plano Nacional de Desestatização - PND, através do qual o Estado brasileiro começou a ser retirado dos setores de siderurgia, exploração de minérios, telecomunicações, energia elétrica, navegação, produção de aeronaves, petroquímica, fertilizantes, etc., reduzindo substancialmente a sua presença em atividades econômicas propriamente ditas.

Não obstante a diminuição, tanto na esfera federal, como estadual e municipal, remanescem existentes sociedades de economia mista relevantes para a economia nacional, tais como a Petróleo Brasileiro S.A. - Petrobras, o Banco do Brasil S.A., a Eletrobrás - Centrais Elétricas Brasileiras S.A. e suas respectivas controladas. A subsistência dessas companhias e a de outras 37 que são negociadas diariamente na BM\&F Bovespa ${ }^{75}$, bem como seu tamanho e a importância de sua condução para o destino do país, são a razão do presente trabalho.

Por fim, antes de prosseguir, vale mencionar que, embora em diversas passagens o Decreto $\mathrm{n}^{\circ} 200$ aluda apenas à possibilidade de criação de estatais por parte da União, isso não impede que Estados, Distrito Federal e Municípios editem leis autorizando a criação de empresas estatais na sua órbita ${ }^{76}$, o que só expande os campos de sua potencial existência.

\footnotetext{
75 MAIA, Bruna. Entre Dois Públicos - A Influência do Governo sobre suas Controladas Incomoda Investidores e Levante o Debate: É Possível Conciliar os Papeis de Estatal e Companhia Aberta?. Revista Capital Aberto, $\mathrm{n}^{\circ}$ 93, maio, 2011, p. 39-41.

76 “[...] 3. Inexiste óbice a que Estado-membro da Federação autorize, por intermédio de Lei Estadual, a criação de sociedade de economia mista estadual, uma que o inciso XIX do art. 37 da
} 


\subsection{Características e peculiaridades da sociedade de economia mista}

As sociedades de economia mista se apresentam na forma jurídica de sociedade anônima. A afirmação se sustenta não apenas no histórico delineado no capítulo anterior, que indica a relação embrionária dos institutos, mas também na atual legislação societária brasileira. O Decreto $n^{\circ}$ 200/1967 é peremptório ao afirmar que a entidade se constitui sob tal forma societária e a Lei $\mathrm{n}^{\circ} 6.404 / 76$ - ou simplesmente Lei das Sociedades Anônimas - dispõe em seu artigo 235 que as sociedades de economia mista estão sujeitas às normas nela contidas, as mesmas aplicáveis as demais sociedades anônimas ${ }^{77}$.

Como é cediço, a sociedade anônima é a principal estrutura jurídica utilizada para a execução de atividade empresária. Naturalmente parte do direito privado, consiste em um instrumento cardinal ao constante desenvolvimento do regime econômico capitalista.

A despeito desse revestimento privado dentro do qual é concebida e de reunir em seu núcleo atributos e peculiaridades inerentes a este tipo societário, a sociedade de economia possui uma característica específica que a diferencia das demais sociedades anônimas: a participação do Estado em seu capital e em sua direção.

O envolvimento estatal anuncia (ou, ao menos, deveria anunciar) a presença de interesse público na atividade econômica exercida pela sociedade, bem como traz para dentro de um instituto eminentemente privado - costumeiramente regrado sob a égide do direito civil e comercial - aspectos pertinentes ao direito público.

Constituição Federal não faz qualquer ressalva à normal geral contida no caput do mesmo artigo, que se fere expressamente à administração pública direta e indireta de quaisquer dos Poderes da União, dos Estados, do Distrito Federal e dos Municípios." (STJ, REsp n ${ }^{\circ} 642.324 / \mathrm{SC}$, Primeira Turma, Rel. Min. Luiz Fux, Brasília, Julg. 12 set. 2006. DJ, 26 out. 2006). Nesse sentido ver também: VENÂNCIO FILHO, Alberto. Sociedades de Economia Mista. In: LAMY FILHO, Alfredo; PEDREIRA, José Luiz Bulhões (Coord.). Direito das Companhias, vol. 2, $1^{\mathrm{a}}$ ed.. Rio de Janeiro: Forense, 2009, p. 1910.

${ }^{77}$ Lei 6.404/1976, art. 235: "As sociedades anônimas de economia mista estão sujeitas a esta Lei, sem prejuízo das disposições especiais de lei federal.” 
As relações em uma sociedade de economia mista são assim submetidas a regras oriundas de regimes jurídicos díspares. Não bastasse, essas regras díspares dispõem-se a orientar a sociedade na busca conjunta e simultânea de interesses e objetivos tão distintos quanto.

$\mathrm{Na}$ qualidade de sociedades anônimas inseridas, em regra, no desempenho excepcional de atividade econômica pelo Estado ${ }^{78}$, a perseguição do interesse dos demais acionistas que não a Administração Pública, ordinariamente materializado em forma de lucro, é da mesma importância que a atenção ao interesse público na direção das sociedades de economia mista.

A congregação desses aspectos de natureza pública e privada em uma única estrutura jurídica é, ao mesmo tempo, o desafio e a justificativa para a existência desse tipo específico de sociedade anônima.

As dificuldades começam cedo, na própria conceituação do instituto. A variedade de elementos que lhe dão forma, agregada a inexistência de uma lei específica sobre as sociedades de economia mista e a dispersão pelo ordenamento das normas lhe dão $\operatorname{traços}^{79}$ tornou historicamente difícil a tarefa de encontrar consenso na definição.

Resumidamente, os doutrinadores concordavam e divergiam em torno de três características: (i) associação de capitais públicos e privados; (ii) o controle e a direção da sociedade pelo Estado; e (iii) a criação por lei.

A primeira corrente exigia tão somente o primeiro requisito. Para seus partidários, a associação de capitais públicos e privados, noção de cunho econômico, é o que caracteriza uma sociedade de economia mista. Fosse verdadeira, não seria descabido compreender como tal qualquer sociedade que tenha em seu capital a participação estatal, ainda que minoritária e sem qualquer direito adicional àqueles conferidos-lhe pela lei

\footnotetext{
78 As sociedades de economia mista podem também exercer serviços públicos, sob o regime a estes aplicáveis.

79 "Em nosso sistema jurídico, as sociedades de economia mista são disciplinadas por meio de normas de diferentes origens e hierarquias: (i) constitucionais; (ii) administrativas; (iii) de direito privado (Lei das S.A.); e (iv) especiais, que são aquelas mediante as quais tais entes são constituídos." (EIZIRIK, Nelson. Op. cit., p. 293)
} 
comum e o estatuto social, isto é, ainda que equiparada aos demais acionistas, sem qualquer prerrogativa ou privilégio ${ }^{80}$. Como se verá, esse não é o caso.

A segunda corrente reúne os autores que acrescem ao primeiro requisito, de cunho econômico, a necessidade da participação estatal na gestão da sociedade. Por sua vez, há ainda uma parcela para qual a caracterização prescinde da questão financeira e da formação do capital social e requer apenas a participação do Estado na gestão da sociedade.

Com relação a terceira e última característica, a criação por lei, a doutrina é mais uníssona ao defender sua indispensabilidade, sob pena de não se afeiçoar uma verdadeira sociedade de economia mista ${ }^{81}$. Conforme anotam Waldemar Ferreira, as sociedades de economia mista no Brasil têm sido criadas por leis especiais, as quais contêm sempre disposições derrogatórias do direito comum, visando assegurar ao Estado o controle absoluto da sociedade ${ }^{82}$. A lei criadora é o que concede o caráter diferenciado à entidade, apontando o fim de interesse público que justifica a intervenção do Estado e delimitando seu escopo.

Firma, portanto, as balizas que permitem o controle da atividade administrativa interventiva, a fim de garantir que a sua condução seja continuamente adstrita aos termos legais ${ }^{83}$.

\footnotetext{
80 "Não se enquadram na categoria de empresas estatais as sociedades destinadas ao desempenho de atividades puramente privadas, com participação minoritária do poder público, mesmo que o ente estatal integre o grupo de controle." (JUSTEN FILHO, Marçal. Op. cit., p. 250)

81 “(...) somente mediante lei autorizadora pode ser criada sociedade sociedade de economia mista. $\mathrm{Na}$ ausência de lei, a companhia não se caracteriza como de economia mista, mas como uma sociedade privada comum, ainda que seu controle seja do Estado, a ela não se aplicando o Capítulo XIX da Lei das S.A.” (EIZIRIK, Nelson. Op. cit., p. 304)

82 "No Brasil, como em quase todos os países, a sociedade de economia mista é criação da lei. Não nasce nenhuma do simples acordo de vontades dos particulares e dos agentes do poder público, como a sociedade privada. É que a sociedade de economista mista há de ter por objeto o interesse público, muitíssimo mais que o interesse particular, colocado na dependência daquele, que é o predominante." (FERREIRA, Waldemar. A Sociedade de Economia Mista em seu Aspecto Contemporâneo. São Paulo: Max Limonad, 1956, p. 133).

83 “"(...) assim, a sociedade de economia mista tem a sua atuação limitada às atividades previstas na lei que autorizou sua criação. Não pode, portanto, dedicar-se a outros empreendimentos não previstos na lei especial que a instituiu e descritos em seu objeto social.” (EIZIRIK, Nelson. Op. cit., p. 307).
} 


\subsubsection{Associação de capitais públicos e privados}

A participação do erário público ao lado de recursos oriundos de bolsos privados no capital social é provavelmente a principal e, talvez, única característica que o cidadão comum destacaria para qualificar uma sociedade como sociedade de economia mista.

O entendimento não é de todo descabido e provém da própria denominação da entidade que destaca na expressão "economia mista" o cunho econômico da qualificação.

Embora seja costumeiramente verificado, o traço mais marcante não é unânime na doutrina como elemento nuclear de tal figura societária, tratando-se, para alguns autores, somente de um elemento acessório a sua configuração $^{84}$, enquanto à gestão conjunta da sociedade caberia o poder de dar forma ao tipo.

Escoimado na redação do Decreto no 200/1967 que, ao definir o instrumento, exige tão somente que as "ações com direito a voto pertençam em sua maioria à União ou a entidade da Administração Indireta" ${ }^{\text {, }}$, Marçal Justen Filho observa que a sociedade de economia mista se diferencia da empresa públicas não pela obrigatoriedade de ter seu capital social composto por recursos públicos e privados, mas pela possibilidade $\mathrm{de}^{86}$. Ao mesmo tempo, porém em sentido contrário, Carvalho Filho aponta exatamente essa característica ao iniciar a explanação das diferenças entre as empresas estatais ${ }^{87}$, apresentando a sociedade de economia mista como aquela onde estão presentes recursos públicos e privados conjuntamente.

\footnotetext{
${ }^{84}$ Há doutrinadores contrários que enxergam na associação de capitais a pedra angular da sociedade de economia mista, para os quais uma sociedade formada apenas com capitais públicos seria uma empresa pública e uma sociedade formada apenas com capitais privados seria uma empresa privada.

${ }^{85}$ Decreto $^{\circ}$ 200/1967, artigo 5º inciso III, com redação alterada pelo Decreto-Lei no 900/1969.

86 "Uma sociedade de economia mista também pode ser formada apenas por sócios integrantes da órbita estatal. Mas isso não é necessário, já que empreendedores privados podem deter participação societária. (...) O controle da sociedade de economia mista deverá ser mantido com uma entidade estatal." (JUSTEN FILHO, Marçal. Op. cit., p. 266)

87 “A primeira diferença consiste na composição do capital. Nas sociedades de economia mista, o capital é formado da conjugação de recursos oriundos das pessoas de direito público ou de outras pessoas administrativas, de um lado, e de recursos da iniciativa privada, de outro. (...) Diversa é composição do capital das empresas públicas. Nestas só é admissível que participem do capital
} 
Com o devido respeito a discussão doutrinária e aos argumentos propostos, não cabe aqui estender muito mais a discussão. Sem dúvida a definição do Decreto é capciosa e, caso Carvalho Filho esteja correto em sua análise, requer o aprimoramento de sua redação ${ }^{88}$. Ocorre, contudo, que a maioria das sociedades de economia mista são aquelas onde há a associação de capitais públicos e privados, as quais, por sua vez, são especialmente relevantes para o presente estudo.

Vale ressaltar que, inobstante a discussão acerca da necessidade da associação de recursos de origens distintas para a perfeita caracterização do tipo societário, não basta a simples participação do erário público no capital social para se configurar uma sociedade de economia mista ${ }^{8990}$. No ordenamento brasileiro, para que o regime diferenciado seja conferido a esse tipo de sociedade anônima, tal fator deverá ser somado a outros que serão vistos a seguir.

\footnotetext{
pessoas administrativas, seja qual for seu nível federativo ou sua natureza jurídica (pública ou privada)." (CARVALHO FILHO, José dos Santos. Op. cit,. p. 502). No mesmo sentido, Tavares Borba: "Na sociedade de economia mista acasalam-se interesses e capitais públicos e privados, ao contrário da empresa pública, cujo capital é inteiramente governamental.” (BORBA, José Edwaldo Tavares. Direito Societário, $13^{\mathrm{a}}$ Ed., São Paulo: Renovar, 2012, p. 516)

${ }^{88}$ Bandeira de Mello questiona o texto do decreto ao comentar os conceitos de empresa pública e sociedade de economia mista. Segundo o autor, "a noção de sociedade de economia mista demanda - e não apenas por força da tradição, mas também para ajustar-se ao espírito de comandos constitucionais - conjugação de capitais de pessoas governamentais com capitais particulares." (BANDEIRA DE MELLO, Celso Antônio. Op. cit., p. 196-197)

89 "Existem sociedades em que o capital pertencente ao Estado, por alguma razão que não interessa indagar neste passo, é minoritário e não possibilita o controle societário. Essas entidades têm sido denominadas sociedades de mera participação do Estado e, além de não integrarem a Administração Pública, não são consideradas sociedades de economia mista." (CARVALHO FILHO. Op. cit., p. 502). Do mesmo entendimento compartilha JUSTEN FILHO, Marçal. Op. cit., p. 250.

${ }^{90}$ Sobre o ponto, vale a explanação de Eros Grau sobre a diferença da sociedade de economia mista para as sociedades com mera participação estatal. Na primeira, em sua interioridade, a organização estatal procede como Estado-poder, conservando parcelas de poder de império, possuindo prerrogativas excepcionais e derrogatórias da legislação comum. Já na segunda, o Estado assume a qualidade de simples acionista, procedendo em igualdade de condições com os demais particulares na mesma posição. (GRAU, Eros. Prestação de Serviços Públicos e Administração Indireta: Concessão e Permissão de Serviço Público, Autarquias, Sociedades de Economia Mista, Empresas Públicas, Fundações Governamentais, $2^{a}$ ed., São Paulo: Revista dos Tribunais, 1987, pp.97-98).
} 


\subsubsection{Criação por lei}

Sem embargo do debate sobre a necessária associação de recursos públicos e privados na formação do seu capital social, a legislação ${ }^{91}$, e posteriormente à própria Constituição Federal $^{92}$, consagraram um entendimento doutrinário dominante ao determinarem que a criação de sociedades de economia mista depende de autorização legislativa ${ }^{93}$.

Conforme bem anota Mauro Penteado, a exigência de autorização legislativa viveu três fases no direito brasileiro: $(i)$ a primeira marcada pelo vazio constitucional e legal, durante a qual o reconhecimento cabia apenas à doutrina; (ii) a segunda, em o requisito tornou-se essencial com definição do tipo societário da sociedade de economia mista na Reforma Administrativa promovida pelo Decreto-Lei no 200/1967 e, mais adiante, em 1976, com a edição da Lei das Sociedades Anônimas; e (c) a última, em que o requisito foi alçado a nível constitucional pelo artigo 37 da Constituição Federal promulgada em $1988^{94}$.

A atenção dispensada ao tema pelo legislador constituinte tem fundamento e resulta da grande proliferação de sociedades de economia mista ao longo das décadas de 70 e 80 , o que dificultou o controle por parte do Estado, mas também pela própria sociedade civil sobre suas atuações. A

\footnotetext{
${ }^{91}$ Decreto $\mathrm{n}^{\circ}$ 200/1967, alterado pelo Decreto $\mathrm{n}^{\circ}$ 900/1969, art. 5: "Para os fins desta Lei, considera-se: (...) III - Sociedade de Economia Mista - a entidade dotada de personalidade jurídica de direito privado, criada por lei para a exploração de atividade econômica, sob a forma de sociedade anônima, cujas ações com direito a voto pertençam em sua maioria à União ou a entidade da Administração Indireta". (grifos nossos)

${ }^{92}$ Constituição Federal de 1988, art. 37: "A administração pública direta e indireta de qualquer dos Poderes da União, dos” Estados, do Distrito Federal e dos Municípios obedecera aos princípios de legalidade, impessoalidade, moralidade, publicidade e eficiência e, também, ao seguinte: (...) XIX - somente por lei específica poderá ser criada autarquia e autorizada a instituição de empresa pública, de sociedade de economia mista e de fundação, cabendo à lei complementar, neste último caso, definir as áreas de sua atuação (...)" (grifos nossos).

${ }^{93} \mathrm{O}$ texto constitucional antes dizia que as sociedades de economia mista eram "criadas" por lei, tendo sido corretamente alterado pela Emenda Constitucional $n^{\circ}$ 19/1998 para que constasse a expressão "autorizada", posto que, por sua natureza de sociedade anônima, a efetiva criação depende da observação dos requisitos dispostos na legislação aplicável a tal tipo societário, notadamente a realização de assembleia de constituição e o registro dos atos constitutivos na Junta Comercial competente. Nesse sentido: CARVALHO FILHO, José dos Santos. Op. cit., p. 492.

${ }^{94}$ PENTEADO, Mauro. As Sociedades de Economia Mista e as Empresas Estatais Perante a Constituição de 1988. Revista de Informação Legislativa, Brasília, a. 26, n. 102, pp. 49-68, 1989, p. 54.
} 
necessidade de autorização legislativa constitui um obstáculo à expansão da Administração indireta e uma forma de impedir uma fuga do sistema de limitação do poder $^{95}$ que se coaduna com a nova ordem econômica constitucional, já mencionado anteriormente.

Importante ressaltar a expressão utilizada pelo texto constitucional: legislação específica. Ainda que não fosse necessário, já que a indeterminação legislativa retiraria todo e qualquer sentido do dispositivo, a Constituição preferiu ser cuidadosa ao impedir explicitamente uma autorização genérica e indeterminada, como, por exemplo, a autorização para a criação de sociedade de economia mista para desenvolver "qualquer atividade comercial ou industrial" ${ }^{\prime 96}$.

Esvaziado também estaria o dispositivo se apenas para criação da entidade da Administração indireta fosse exigido lei autorizadora, sendo permitido a essas instituírem sociedades controladas com objetos diversos àqueles previstos na legislação específica que permitiu a sua própria criação. Nesse sentido, a jurisprudência do Supremo Tribunal Federal impede esse malabarismo legal e somente reconhece como válida a criação de sociedades controladas se estas envolverem o desempenho da atividade empresarial disciplinada na lei autorizadora, configurando tão somente uma opção de organização societária ${ }^{97}$.

Respeitadas as opiniões contrárias, parece não mais ser possível argumentar contrariamente a necessidade da autorização legislativa para a criação de sociedades de economia mista ${ }^{98}$.

\footnotetext{
${ }^{95} \mathrm{O}$ dispositivo decorre do propósito de evitar a criação indiscriminada dessas empresas, sujeita a sua criação ao crivo do Poder Legislativo, examinada sob os aspectos de conveniência e necessidade.

${ }^{96}$ JUSTEN FILHO, Marçal. Op. cit., p. 251-252.

97 “(...) 2. É dispensável a autorização legislativa para a criação de empresas subsidiárias, desde que haja previsão para esse fim na própria lei que instituiu a empresa de economia mista matriz, tendo em vista que a lei criadora é a própria medida autorizadora. Ação direito de inconstitucionalidade julgada improcedente." (STF, ADI n ${ }^{\circ}$ 1.649/DF, Pleno. Rel. Min. Mauricio Correa, Brasília, Julg. 24 mar. 2004, DJe, 28 mai. 2014). No mesmo sentido: CARVALHO FILHO. Op. cit., p. 493.

${ }^{98}$ Em seu raciocínio para justificar a necessidade de autorização legislativa, Eros Grau argumenta que, se o que confere a qualidade jurídica de economia mista é a outorga de prerrogativas e privilégios ao Estado para cumprimento do interesse público, mediante a derrogação de normas de direito comum que regem as sociedades anônimas, e o instrumento através do qual se faz isso é a
} 


\subsubsection{Controle e direção estatal}

A característica que certamente sucederia a associação de capitais públicos e privados na caracterização das sociedades de economia mista pelo homem comum é o controle estatal da companhia.

O poder de controle, definido pelo Lei da S.A. no artigo $116^{99}$, "consiste no poder jurídico de determinar o destino da sociedade, o que se traduz essencialmente na eleição da maioria dos administradores da companhia, submetendo-os à observância de diretivas e orientações" ${ }^{\prime 100}$.

Com efeito, é exatamente a esse poder que se remete o artigo $5^{\circ}$ do Decreto-Lei no 200/1967 ao incluir na definição da entidade a necessidade de que as "ações com direito a voto pertençam em sua maioria à União ou a entidade da Administração Indireta". São essas ações com direito à voto, as quais devem pertencer ao Estado ${ }^{101} \mathrm{em}$ uma sociedade de economia, que concedem ao acionista detentor o poder de dirigir a companhia. Como a exigência não consiste em ações que representem a maioria do capital social, mas sim a maioria do capital votante, nada impede que o Estado não seja o acionista com maior participação no capital total ${ }^{102}$.

$\mathrm{Na}$ opinião de Marçal Justen Filho, é perfeitamente possível que o controle seja exercido conjuntamente com agentes privados, através da celebração de acordo de acionistas ${ }^{103}$. Nesse caso, a manutenção do caráter

lei especial, não há como se conceber a existência de sociedade de economia mista sem lei autorizadora. (GRAU, Eros. Op. cit., p. 132)

99 A Lei 6.404/1976 define "acionista controlador" no artigo 166 que possui a seguinte redação: "Entende-se por acionista controlador a pessoa, natural ou jurídica, ou o grupo de pessoas vinculadas por acordo de voto, ou sob controle comum, que: a) é titular de direitos de sócio que lhe assegurem, de modo permanente, a maioria dos votos nas deliberações da assembleia geral e o poder de eleger a maioria dos administrados da companhia; e b) usa efetivamente seu poder para dirigir as atividades sociais e orientar o funcionamento dos órgãos da companhia." No mesmo sentido, o artigo 243, parágrafo $2^{\circ}$, da mesma Lei, estabelece ser controlada a sociedade na qual a controladora, diretamente ou por meio de outra controlada, é titular de direitos de sócio que lhe assegurem, de modo permanente, preponderância nas deliberações sociais e o poder de escolher a maioria dos administradores.

100 JUSTEN FILHO, Marçal. Op. cit., p. 265.

101 Como já se viu, embora o dispositivo mencione "União" o entendimento correto é que os outros entes federativos - Estados, Distrito Federal e Municípios - também podem constituir sociedade de economia mista.

${ }^{102}$ EIZIRIK, Nelson. Op. cit., p. 312.

103 "Podemos identificar, em nossa prática societária, as seguintes modalidades de controle acionário: (i) o majoritário, quando o controlador, direta ou indiretamente, detém a maioria das 
de sociedade de economia mista exigiria que ao Estado continuasse cabendo a eleição da maioria dos diretores ou a orientação dos órgãos societários $^{104}$.

Alguns autores heterodoxos discutem a possibilidade do Estado assumir a direção da sociedade sem deter participação majoritária no capital votante, ou mesmo sem qualquer participação no capital social ${ }^{105}$, mediante as derrogações de lei especial que autorize sua criação. Desta situação decorreria a possibilidade ter uma sociedade de economia mista minoritária, tipo que, vale ressaltar, não existe no direito brasileiro. Ainda que existisse, parece difícil imaginar que investidores particulares aplicariam capital em uma sociedade conduzida pelo Estado para realização de um interesse público, muitas das vezes conflitante com o interesse privado concretizado no lucro.

\subsubsection{Fim de interesse público}

Embora fundamental à caracterização e justificativa da própria existência do instituto, a última característica peculiar das sociedades de economia mista parece ausente do rol padrão de elementos que the caracterizam na concepção do homem comum $^{106}$.

O texto da Lei das S.A. foi infeliz ao utilizar a expressão "mas poderá" no dispositivo que determina como deverá agir o acionista controlador - o Estado - no exercício do poder de controle no âmbito das sociedades de economia mista:

\footnotetext{
ações com direito de voto; (ii) o compartilhado, que é aquele exercido por várias pessoas em conjunto, geralmente como signatários de acordo de acionistas, que se obrigam a votar em bloco nas matérias atinentes ao exercício do poder de controle; e (iii) o minoritário, que se caracteriza quando, dada a dispersão de ações da companhia no mercado, 1 (um) acionista ou grupo de acionistas exerce o poder de controle com menos da metade do capital votante, posto que nenhum outro acionista ou grupo detém maior numero de ações com direito de voto.” (Ibid., p. 312)

${ }^{104}$ JUSTEN FILHO, Marçal. Op. cit., p. 265.

105 SANTOS, Theophilo de Azeredo. Op. cit., p. 46.

106 Trata-se de conceito do qual só se toma conhecimento ou em discursos da Administração Pública, ou de partidários da intervenção do Estado nas atividades econômicas, em defesa de decisões tomadas pelo ente federativo na condução de tais companhias.
} 
"Art. 238. A pessoa jurídica que controla a companhia de economia mista tem os deveres e responsabilidades do acionista controlador (arts. 116 e 117), mas poderá orientar as atividades da companhia de modo a atender ao interesse público que justificou sua criação." (grifos nossos)

A conotação de possibilidade poderia dar a falsa ideia de que, em regra, o acionista controlador não estaria obrigado a orientar as atividades para atender ao interesse público que justificou a criação da sociedade.

Bem mais precisa foi a letra da Constituição ao limitar o exercício pelo Estado de atividade econômica propriamente dita. Corporificado na exigência de relevante interesse coletivo, o caráter de suplementariedade restrita da atuação direta da Administração Pública é a base de modulação da atual ordem econômica constitucional.

Ao contrário daquilo que a Lei das S.A. eventualmente poderia transmitir, a sociedade de economia só pode existir se houver um interesse público a perseguir através de sua criação e, uma vez criada, tal perseguição passa a ser dever do Estado, sob pena de desvio de finalidade ${ }^{107108}$.

\subsubsection{Natureza jurídica e regime normativo aplicável}

A constituição sobre a forma de sociedade anônima, entidade societária pertinente ao direito privado $^{109}$, não afastou toda e qualquer discussão sobre a natureza jurídica da sociedade de economia mista.

A formação mista de seu capital e a presença indispensável da participação estatal suscitou um debate histórico sobre a eventual do seu status jurídico, originalmente privado. Pergunta-se: transmuda a sociedade

\footnotetext{
${ }^{107}$ COMPARATO, Fábio Konder. Sociedade de Economia Mista Transformada em Sociedade Anônima Ordinária - Inconstitucionalidade. Revista Trimestral de Direito Público, São Paulo, n. 25, pp. 61-68, 1999, p. 63.

${ }^{108}$ A Lei no $4.717 / 1965$, que regula a ação popular, define desvio de finalidade em seu artigo $2^{\circ}$, parágrafo único, letra $e$ : "e) o desvio de finalidade se verifica quando o agente pratica o ato visando a fim diverso daquele previsto, explícita ou implicitamente, na regra de competência".

${ }_{109}$ Nesse sentido, ver Decreto $\mathrm{n}^{\circ}$ 200/1967, artigo $5^{\circ}$, inciso III, com redação alterada pelo Decreto-Lei nº 900/1969; Constituição Federal, art. 173, §1, inciso II; e Lei 6.404/76, art. 235, caput.
} 
em pessoa jurídica de Direito Público pela penetração do poder público e, consequentemente, do interesse público?

O debate se organizava em torno de três correntes: (i) a primeira, defensora do caráter público, justificando-se não apenas na presença estatal na estrutura societária, mas na direção da sociedade em prol do interesse público para o qual foi construída; (ii) a segunda é expoente do caráter privado, para a qual o Estado, ao adotar forma de empresa, insere-se no âmbito dos negócios, torna-se empresário e deve operar dentro do mesmo campo jurídico $^{110}$; e (iii) por fim, a natureza híbrida, resultante de um tipo intermediário, sujeito ao mesmo tempo às normas do direito privado e às normas do direito público ${ }^{111}$.

Como bem lembram Carvalho Filho e Hely Lopes Meirelles, a concessão de natureza privada a esse instrumento à disposição da Administração Pública tem um objetivo. A criação desse tipo de pessoa jurídica de natureza empresarial, eminentemente privada, concede mais versatilidade e flexibilidade ao exercício de atividades econômicas sob direção institucional do Estado. A utilização de pessoas administrativas envoltas pelo regime tradicional de direito público, presas a um imenso aparato burocrático de controle, provocaria lentidão nas atividades desempenhadas, fato incompatível com a celeridade e a eficiência que o exercício da atividade econômico requer ${ }^{112}$.

Não obstante sua validade doutrinária, parece-nos que o ritmo da discussão deveria arrefecer com o reconhecimento pela Constituição Federal de 1988 - seguindo legislação infraconstitucional já bastante clara

\footnotetext{
${ }^{110}$ BORBA, José Edwaldo Tavares. Sociedade de Economia Mista e Privatização. Rio de Janeiro: Lumen Juris, 1997, p. 29.

111 "As sociedades de economia mista e as empresas públicas, como se tem observado até o momento, exibem dois aspectos inerentes à sua condição jurídica: de um lado, são pessoas jurídicas de direito privado e, de outro, são pessoas sob o controle do Estado. Esses dois aspectos demonstram, nitidamente, que nem estão elas sujeitas inteiramente ao regime de direito privado nem inteiramente ao de direito público. $\mathrm{Na}$ verdade, pode dizer-se, como o fazem alguns estudiosos, que seu regime tem certa natureza hibrida, já que sofrem o influxo de normas de direito privado em alguns setores de sua atuação e normas de direito público em outros setores. $\mathrm{E}$ nem poderia ser de outra forma, quando se analise seu revestimento de direito privado e sua ligação com o Estado." (CARVALHO FILHO, José dos Santos. Op. cit., p. 496)

112 Ibid., p. 491; EIZIRIK, Nelson. Op. cit., p. 294; MEIRELLES, Hely Lopes. Op. cit., p. 333.
} 
sobre a questão ${ }^{113}$ - da natureza de direito privado das empresas estatais exploradoras de atividade econômica, gênero no qual estão incluídas a sociedade de economia mista e as empresas públicas ${ }^{114}$.

O parágrafo $1^{\circ}$ do artigo 173 do texto constitucional é categórico e não deixa qualquer margem para dúvidas:

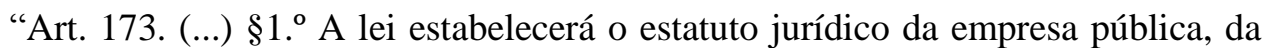
sociedade de economia mista e de suas subsidiarias que explorem atividades econômica de produção ou comercialização de bens ou prestação de serviços, dispondo sobre: (...) II - a sujeição ao regime jurídico próprio das empresas privadas, inclusive quanto aos direitos e obrigações civis, comerciais, trabalhistas e tributários; (...)" (grifos nossos) $)^{115}$

O regime precipuamente de direito privado não impede eventuais derrogações provenientes do regime público, o que, por sua vez, não descaracteriza a natureza privada da entidade. Segundo Gilberto Bercovici, a natureza jurídica de direito privado é um expediente técnico que não afasta integralmente o direito administrativo, sob pena de inviabilizar a sociedade de economia mista como instrumento de atuação do Estado ${ }^{116}$.

A própria Lei das Sociedades Anônimas entre os artigos 235 e 240 alude à sociedade de economia mista indicando um regime anômalo, composto pela submissão às normas gerais aplicáveis às sociedades

\footnotetext{
113 O artigo $5^{\circ}$, inciso II, do Decreto-Lei $n^{\circ}$ 200/1967, com redação alterada pelo Decreto n ${ }^{\circ} 900 / 1969$, ao definir a sociedade de economia mista, é preciso ao imputar-lhe o caráter privado. No mesmo sentido, o artigo 235 da Lei 6.404/76, submete a entidade à legislação societária aplicada à sociedade anônima, vinculando-a assim às regras de direito privado e reafirmando sua natureza original.

${ }^{114}$ Há uma discussão se ao mencionar "atividade econômica" o legislador constituinte quis selecionar apenas as atividades econômicas em sentido estrito, ou se pretendia a expressão genérica, englobando a prestação de serviços. Um debate que também envolve a questão consiste na dúvida sobre o regime jurídico das empresas públicas e sociedades de economia mista que sejam prestadoras de serviços públicos. Contudo, tal discussão foge ao objeto precípuo do presente trabalho e não será abordada em detalhes. Ver mais sobre o tema em: GRAU, Eros. A Ordem Econômica na Constituição de 1988, 15ª ed., revista e atualizada, São Paulo: Malheiros, 2012.

${ }^{115}$ A característica foi ainda acentuada no parágrafo $2^{\circ}$ do mesmo artigo 173 , da Constituição Federal, que determina as empresas públicas e as sociedades de economia mista não poderão gozar de privilégios fiscais não extensivos às do setor privado. Há ainda outros dispositivos no plano constitucional que reafirmam, implícita e explicitamente, a igualdade de regimes.

${ }^{116}$ BERCOVICI, Gilberto. Atuação do Estado no Domínio Econômico e Sistema Financeiro Nacional. Inexigibilidade de Licitação em Incorporação ou em Alienação do Controle de uma Sociedade de Economia Mista por outra Sociedade de Economia Mista. Revista de Direito Mercantil, Industrial, Econômico e Financeiro, São Paulo, n. 148, p. 233-270, 2007, p. 238.
} 
anônimas, desde que não alteradas pelas regras contidas na legislação especial que autorizou sua criação ${ }^{117}$. A disciplina do tipo societário por normas de origens e hierarquias diferentes - constitucionais, administrativas, societárias e especiais - reflete sua característica peculiar, definida por Eizirik como pessoa jurídica de natureza privada sui generis ${ }^{118}$. $\mathrm{O}$ fato de integrarem a Administração Pública indireta e configurarem verdadeiros instrumentos de atuação estatal ${ }^{119}$ submete às sociedades de economia mista, assim como as empresas públicas, a alguns aspectos de Direito Público, sobretudo no que concerne aos princípios norteadores da atividade administrativa, contidos no artigo 37, caput, da Constituição Federal de $1988^{120}$, e na persecução do interesse público. Incidem, assim, normas de direito público naqueles aspectos ligados especialmente ao controle e a fiscalização administrativa ${ }^{121}$. Na própria Constituição, encontramos diversos dispositivos que determinam (i) o controle e fiscalização das sociedades de economia mista pelo Poder Legislativo e pelo Tribunal de Contas (art. 49, X, e art. 70 e $71^{122}$ ); (ii) a extensão da vedação à acumulação de cargos públicos aos empregados da entidade (art. 37, XVI e XVII); (iii) a exigência de concurso público para ingressos de seus empregados (art. 37, II); (iv) a obrigatoriedade de

\footnotetext{
${ }^{117}$ Lei 6.404/1976: "Art. 235. As sociedades anônimas de economia mista estão sujeitas a esta Lei, sem prejuízo das disposições especiais de lei federal.” (grifos nossos)

${ }^{118}$ EIZIRIK, Nelson. Op. cit., p. 295.

${ }^{119}$ DI PIETRO, Maria Sylvia Zanella. Direito Administrativo, 25 a ed., São Paulo: Atlas, 2012, p. 503.

${ }^{120}$ Constituição Federal de 1988, art. 37: “A administração pública direta e indireta de qualquer dos Poderes da União, dos" Estados, do Distrito Federal e dos Municípios obedecera aos princípios de legalidade, impessoalidade, moralidade, publicidade e eficiência e, também, ao seguinte: (...)"

${ }^{121}$ BARROSO, Luis Roberto. Intervenção do Domínio Econômico - Sociedade de Economia Mista - Abuso do Poder Econômico. Revista de Direito Administrativo, Rio de Janeiro: Renovar, v. 212, 1998, p. 310.

${ }^{122}$ Constituição Federal de 1988, art. 49: "É da competência exclusiva do Congresso Nacional: (...) $\mathrm{X}$ - fiscalizar e controlar, diretamente, ou por qualquer de suas Casas, os atos do Poder Executivo, incluídos os da administração indireta; (...)" (grifos nossos); Constituição Federal de 1988, art. 70: "A fiscalização contábil, financeira, orçamentária, operacional e patrimonial da União e das entidades da administração direta e indireta, quanto à legalidade, legitimidade, economicidade, aplicação das subvenções e renuncia de receitas, será exercida pelo Congresso Nacional, mediante controle externo, e pelo sistema de controle interno de cada Poder."; Constituição Federal de 1988, art. 71: "O controle externo, a cargo do Congresso Nacional, será exercido com o auxilio do Tribunal de Contas da União, ao qual compete: (...)".
} 
licitação (art. $173, \S 1^{\circ}$, III $)^{123} ;(v)$ a previsão de rubrica orçamentária (art. $\left.165, \S 5^{\circ}\right)$, dentre outras do gênero.

A submissão a essas regras peculiares do regime de direito público ${ }^{124}$ não afasta em qualquer medida a preponderância da orientação privada da atuação das sociedades de economia mista. A regra geral estabelecida no artigo 173, $\S 1^{\circ}$, II, da Constituição Federal de 1988 permanece intacta.

Sobre a questão, atento à proteção do regime econômico de economia de mercado que ele próprio consagrou, o texto constitucional estabeleceu que as empresas estatais, ao contrário das demais pessoas públicas, não devem ter nenhum privilegio que as beneficiem e que não sejam estendidos às empresas privadas, especialmente no que concerne às suas obrigações civis, comerciais, trabalhistas e tributárias ${ }^{125}$. A intenção de igualá-las é evidente.

Alinhada no mesmo sentido está a Lei das Sociedades Anônimas, estabelecendo a submissão da entidade às mesmas regras às quais submete todas as demais sociedades anônimas que regula. A similaridade sequer exigiria, mas a lei preferiu ser explícita ao sujeitar as sociedades de economia mista de capital aberto - como é o caso da maioria delas - às normas da Comissão de Valores Mobiliários - CVM, órgão regulador e

\footnotetext{
123 "I - O Banco de Brasília, sociedade de economia mista, conforme art. 4", alínea $c$, do DecretoLei $n^{\circ}$ 200/67, é órgão da Administração Pública Indireta e, como órgão esta categoria, para adquirir bens e contratar obras e serviços de terceiros, deve sujeitar-se à realização de licitação pública, conforme dispõe o art. 37, XXI, da Constituição Federal. II - Dessarte, os atos administrativos praticados por entidades de economia mista, sujeitos ao disciplinamento da Lei $\mathrm{n}^{\circ}$ 8.666/93, são tidos como atos de 'autoridade', sendo passíveis de serem controlados mediante a via mandamental.” (STJ, REsp no 470.329/DF, Primeira Turma. Rel. Min. Francisco Falcão, Brasília, Julg. 20 abr. 2006. DJ, 15 mai. 2006).

124 "Ou seja, a sociedade de economia mista, em princípio, é regida pelas mesmas normas que disciplinam as demais sociedades por ações, as quais somente podem ser afastadas quando houver previsão legal expressa a respeito em norma de direito público. Nesse sentido, é clássica a consideração doutrinaria de que a sociedade de economia mista é privada quoad extra, isto é, em relação aos terceiros com quem se relaciona, e público quoad intra, ou seja, em suas relações com a entidade pública pela qual foi criada, como instrumento de intervenção estatal no domínio econômico, nas quais se assegura o predomínio da Administração Pública." (EIZIRIK, Nelson. Op. cit., p. 298)

125 "Inexistem, pois, privilégios materiais e processuais, como os atribuídos às entidades públicas, de que são exemplo as autarquias. O STJ consagrou tal diretriz, editando súmula que, no caso de responsabilidade civil, equipara o prazo de prescrição de pretensão indenizatória contra sociedades de economia mista ao prazo fixado para as entidades do setor privado, diferentemente do que ocorre com as pessoas públicas, favorecidas com a prescrição qüinqüenal.” (CARVALHO FILHO, José dos Santos. Op. cit., p. 496)
} 
fiscalizar do mercado de capitais ${ }^{126}$. Não cabe aqui qualquer argumento que busque diferenciar a sociedade de economia mista de capital aberto das demais sociedades anônimas de capital aberto no intuito de escapar da órbita do órgão, sob pena de violação do princípio da isonomia ${ }^{127}$.

Ao que pese a verificação de alguns aspectos típicos do regime público na estrutura das sociedades de economia mista, o melhor entendimento sustenta que ao atuar diretamente no mercado a Administração Pública desce do "pedestal público", onde naturalmente se encontra. A expressão significa o abandono de prerrogativas especiais que o regime de direito público lhe confere e a submissão às mesmas regras que regem a atuação de particulares no exercício de atividade econômica. Merece esclarecer que eventuais derrogações das regras de direito privado são permitidas pela lei autorizadora da criação de sociedades de economia, em especial atenção ao caráter de interesse público que lhes circundam. Os limites de tais derrogações encontram-se nos elementos fundamentais da economia de mercado e do regime privado das relações que a Constituição procurou proteger, bem como na perigosa definição do que seja interesse público e seu status jurídico.

\subsection{Conclusão do capítulo}

A conjugação de todas essas características peculiares no âmbito de uma relação societária inevitavelmente gera dificuldades e ruídos. A promoção do interesse público, que deve dirigir toda atuação da Administração Pública e que justifica a participação dos entes federativos em sociedades de economia mista, invariavelmente vai de encontro ao

\footnotetext{
${ }^{126}$ Lei $6.404 / 76$, art. $235, \S 1^{\circ}$ : “As companhias abertas de economia mista estão também sujeitas às normas expedidas pela Comissão de Valores Mobiliários."

127 "Não pode a sociedade de economia mista invocar o interesse público para descumprir as normas baixadas pela Comissão de Valores Mobiliários para regular as companhias abertas. Especialmente no que se refere ao princípio da transparência (disclosure), fundamental na regulação do mercado, devem os administradores da companhia aberta de economia mista, da mesma forma que os das demais companhias abertas, divulgar imediatamente as informações relevantes ocorridas em seus negócios.” (EIZIRIK, Nelson. Op. cit., p. 299).
} 
interesse privado dos demais acionistas que compõe a capital social. A participação do Estado, por sua vez, traz para dentro de uma entidade de natureza primordialmente privada aspectos específicos do Direito Público.

Essa é a origem do desafio que a estrutura jurídica da sociedade de economia mista visa equilibrar. 


\section{TERCEIRA PARTE}

\section{A ESTRUTURA HÍBRIDA E OS DESAFIOS DE} CONCILIAÇÃO

\subsection{O interesse público como fundamento da atividade econômica estatal e o princípio da subsidiariedade}

No terceiro ponto da primeira parte, vimos que a Constituição estabeleceu as bases sobre as quais deve se pautar a atuação direta do Estado como agente econômico, compreendendo tanto a atividade econômica propriamente dita, quanto a prestação de serviços. O caput do seu artigo 173 merece transcrição:

\footnotetext{
“Art. 173: Ressalvados os casos previstos nesta Constituição, a exploração direta de atividade econômica pelo Estado só será permitida quando necessária aos imperativos da segurança nacional ou a relevante interesse coletivo, conforme definidos em lei." (grifos nossos)
}

Além daqueles casos antecipada e expressamente previstos, restou definido que seria permitida a atuação da Administração Pública como exploradora de atividades econômicas nos casos necessários aos imperativos da segurança nacional ou pertinentes a relevante interesse coletivo.

A hipótese da segurança nacional não demanda maiores dificuldades. Julgamos ser inquestionável a ressalva constitucional nas situações em que esteja em jogo a proteção da soberania e do território nacional, de modo que as grandes dificuldades surgem das hipóteses que envolvem o "relevante interesse coletivo".

Primeiramente, vale mencionar que alguns doutrinadores defendem que a utilização pelo constituinte do termo interesse coletivo pretendeu diferenciá-lo do que até aqui tratamos como interesse público. Para Emerson Gabarda, o interesse público pode consistir na proteção de um 
interesse individualizado e, ao contrário do que acontece em outras formas de intervenção estatal na economia, o Estado não pode atuar diretamente para proteger um interesse individualizado. Nesse sentido, a expressão interesse coletivo simbolizaria um interesse público difuso e não individualizado $^{128}$.

Também é destacável o termo relevante, mediante o qual atribuiu-se à semântica a função de reforçar o caráter restritivo imputado à atuação direta pela ordem econômica estabelecida com a Constituição Federal de 1988.

Mas fato é que o artigo 173 da Carta Magna usou um conceito jurídico indeterminado para definir uma hipótese de natureza restritiva. Como já mencionado, o conceito de interesse público - que para a maioria se confunde com o interesse coletivo proposto por Gabarda - é bastante controverso e dá origem a fervorosos debates doutrinários. Autores de diversas épocas e escolas, como Friedrich Hayek e Calixto Salimão, chegam a opinar pela impossibilidade de uma definição precisa e "hegemônica".

Por sua vez, Tércio Sampaio Ferraz aduz que o interesse público é lugar-comum e, justamente por isso, dispensa definição precisa e permite a utilização mais eficiente ${ }^{129}$. Mais adiante, veremos que sua vagueza não configura uma vantagem, muito pelo contrário, prejudica enormemente o controle da atuação da Administração Pública ao permitir uma maleabilidade excessiva ao gosto dos interesses governamentais momentâneos.

Marçal Justen Filho também defende a completa ausência de conteúdo do "interesse público", mas para justificar uma posição divergente. Partindo de uma conceituação às avessas - isto é, daquilo que ele não é -, chega a conclusão que o conceito representa interesses privados

\footnotetext{
${ }^{128}$ GABARDA, Emerson. Interesse Público e Subsidiariedade. Belo Horizonte: Fórum, 2009, p. 27.

${ }^{129}$ FERRAZ JUNIOR, Tércio Sampaio. Interesse Público. Revista do Ministério Público do Trabalho da $2^{\text {a }}$ Região. Disponível em: http://www.prt2.gov.br/revl.shtml. Acessado em 15 mai. 2015.
} 
de natureza diferenciada, que por sua natureza não egoística e sua indiscutível relevância ganham caráter de publicidade ${ }^{130}$. São esses direitos, denominados direitos fundamentais, que guardam o verdadeiro núcleo da atividade estatal.

Sem embargos de uma infinidade de divergências nos ajustes finos, a doutrina majoritária costuma definir interesses públicos como os interesses da coletividade como um todo, que transcendem os interesses individuais de cada cidadão, e que foram alçados a um posto de maior relevância pela Constituição, constituindo o próprio objetivo e a função do Estado.

Não fosse suficiente a nebulosidade que se estende sobre a definição do que seja interesse público, outra grande problemática quanto à atuação direta do Estado circunda a sua subsidiaridade. Trata-se da existência do critério residual, segundo o qual, ainda que verificada a existência de interesse público na realização de determinada atividade econômica, só caberá atuação direta do Estado quando houver defeito na atuação dos particulares e na medida de tais faltas ${ }^{131}$.

Os autores contrários ao princípio da subsidiariedade argumentam que a livre iniciativa, fundamento da ordem econômica conforme artigo 170 da Constituição Federal de 1988, pode ser legitimamente limitada por medidas adotadas pelo Estado, posto que este também é dotado de iniciativa econômica, como, por exemplo, na atuação em setores que lhe são

\footnotetext{
${ }^{130}$ Nesse contexto, alinhado com o ponto de Gabarda, Marçal propõe a adoção do termo "interesse coletivo" no lugar de "interesse público", mas o faz mesmo fora do contexto do artigo 173 da Constituição e de forma generalizada. A conclusão de que os interesses públicos nada mais são do que interesses privados de qualidade diferenciado, faz com que admita-se a sua titularidade individual, coletiva ou difusa. Sendo assim, a atuação da Administração Pública não pautada pelo interesse público, mas sim pelos interesses coletivos. (JUSTEN FILHO, Marçal. Op. cit., p. 118$123)$.

${ }^{131}$ Sobre o princípio da subsidiariedade no direito administrativo: "A subsidiaridade prescreve o escalonamento de atribuições entre entes ou órgãos, em função da complexidade do atendimento dos interesses das sociedades. Cabe, assim, primariamente aos indivíduos decidirem e agirem no que se refira aos seus respectivos interesses individuais, e, apenas secundária e sucessivamente, aos entes e órgãos, sociais e políticos, instituídos para tomar decisões sobre interesses coletivos. (...) Assim, somente as demandas que, por sua própria natureza, em razão da complexidade e da necessidade de uma ação concentrada e coercitiva, inclusive com centralização de recursos, não puderem ser atendidas pela própria comunidade através de suas organizações, deverão ser cometidas às organizações políticas, que atuarão, portanto, subsidiariamente às da sociedade." (MOREIRA NETO, Diogo de Figueiredo. Curso de Direito Administrativo. Op. cit., p. 96).
} 
privativos, no exercício do poder regulador e fiscalizador, ou na própria possibilidade de iniciativa econômica pelo Estado, etc.

Para Gilberto Bercovici, o Estado pode e deve atuar na esfera econômica e social, legitimado que é pelos ditames constitucionais, e o fato da intervenção direta ocorrer sob a justificativa dos imperativos da segurança nacional e do relevante interesse coletivo não implica na subsidiariedade da atuação estatal. Nesse sentido, conclui que a amplitude maior ou menor da atuação econômica do Estado é consequência de decisões políticas, não de alguma determinação constitucional expressa ${ }^{132}$.

Já para os defensores do princípio da atuação residual a atuação direta estatal não é justificável mediante a mera invocação de algum interesse público que se considere relevante. Sua validação requer a observação do princípio da subsidiariedade, que entra em cena aqui como consectário do princípio da proporcionalidade quando aplicado na atuação estatal no domínio econômico.

Esse último consiste na averiguação de alguns parâmetros na conduta da Administração Pública: (a) a adequação entre o fim perseguido e a medida empregada; (b) a necessidade da medida, consistente na inexistência de meio alternativo menos gravoso para chegar ao mesmo resultado; e (c) a proporcionalidade em sentido estrito, que nada mais é senão uma relação de custo e benefício positiva, isto é, ganha-se mais do que perde-se.

Segundo o princípio da subsidiariedade, alicerçado nos mesmos critérios, a intervenção estatal direta só se legitima quando for esta adequada e imprescindível para a satisfação de determinada necessidade, isto é, se não houver outra alternativa mais satisfatória para persecução do interesse coletivo $^{133}$. Em resumo, havendo outra forma de atingir o mesmo

\footnotetext{
${ }^{132}$ BERCOVICI, Gilberto. Direito Econômico do Petróleo e dos Recursos Minerais, $1^{a}$ ed.., São Paulo: Quartier Latin, 2011, p. 266-271.

${ }^{133}$ JUSTEN FILHO, Marçal. Op. cit., p. 808; CARVALHO FILHO, José dos Santos. Op. cit., p. 41.
} 
objetivo, restringindo de forma menos gravosa a liberdade individual, a atuação direta do Estado deverá ser sempre preterida em seu favor ${ }^{134}$.

Essa segunda corrente nos parece mais alinhada com a ordem econômica estabelecida pela Constituição Federal de 1988, a qual, tanto em seu contexto geral quanto em normas específicas, reconheceu a primazia da iniciativa privada sobre a iniciativa estatal no papel principal de exploradora de atividades econômicas, preterindo a atuação direta do Estado em favor da intervenção no domínio econômico através das atividades de regulação, fiscalização e fomento da própria iniciativa privada.

Ao que pese o texto do artigo 173 não ter sido expresso nesse sentido, a Constituição consagrou elementos básicos da economia de mercado como liberdades individuais. Nesse contexto, a livre iniciativa como fundamento e os princípios da livre concorrência, da liberdade de contratar e da liberdade de empresa como diretores da ordem econômica estabelecida dão o tom da preferência constitucional pela realização de atividade econômica pelos agentes particulares. A forma residual que deve ser verificada na iniciativa empresarial pública deve estar, portanto, atrelada aos princípios corretivos, termo cunhado por Eizirik e já mencionado anteriormente.

\subsection{O princípio da supremacia do interesse público}

O imbróglio sobre o interesse público é ainda permeado por outras incertezas, que dão origem a mais debates jurídicos infindáveis. De mãos dadas com a querela acerca da definição do seu próprio conceito está a

\footnotetext{
134 "No regime constitucional brasileiro, como em muitos outros, vigora o princípio da subsidiariedade da intervenção estatal no domínio econômico, nos termos do qual a atividade do Estado na economia não se auto justifica. Sua presença somente deve ocorrer no caso de defeito da atividade dos particulares ou da sociedade e na medida de tais faltas. Tal princípio resulta num critério residual de atribuições de funções ao Estado; na falta de soluções por parte dos indivíduos ou dos organismos sociais cabe a atuação estatal, ou para preencher os vazios por ela deixados, ou para estimular a iniciativa privada.” (NELSON, Eizirik. Op. cit., p. 290)
} 
discussão sobre a existência e os contornos do princípio da supremacia do interesse público.

Resumidamente mencionado na primeira parte do trabalho, o significado do princípio consiste exatamente naquilo que sua denominação sugere: em caso de conflito, os interesses públicos devem sempre prevalecer sobre os interesses privados ${ }^{135}$.

Seus defensores argumentam que o ordenamento constitucional, embora proteja os interesses individuais, consagrou a proteção e promoção do interesse público como finalidade imperativa e indisponível da Administração Pública, responsável pela orientação geral de sua atuação ${ }^{136}$. O interesse público consiste hoje no fim último do Estado, o que traduziria uma intenção implícita de permitir a restrição dos interesses individuais em prol da promoção do bem-estar coletivo.

Hely Lopes Meireles aponta que a verticalidade nas relações travadas entre a Administração Pública e os administrados, bem como todas as prerrogativas da primeira na qualidade de protetora dos interesses da coletividade, decorreriam em última analise do reconhecimento pelo ordenamento de que os interesses públicos ocupam uma categoria hierárquica superior a dos interesses privados ${ }^{137}$.

Embora mencionado na grande maioria dos manuais de direito administrativo e constitucional, o princípio da supremacia do interesse público é alvo de doutrinadores que propugnam sua "desconstrução".

Com efeito, chama atenção a existência de um princípio que afirme antecipadamente a preponderância absoluta e ilimitada de uma determinada posição jurídica em abstrato. Os princípios se diferenciam das normas constitucionais binárias exatamente pela necessidade de gradação na sua

\footnotetext{
${ }^{135}$ DI PIETRO, Maria Sylvia Zanella. Op. cit., p. 65-68.

${ }^{136}$ OSÓRIO, Fabio Medina. Existe uma Supremacia do Interesse Público sobre o Privado no Direito Administrativo Brasileiro?. Revista de Direito Administrativo, n. 220, Renovar, 2000, p. 69-107; BANDEIRA DE MELLO, Celso Antônio. Op. cit., p. 99-101.

${ }^{137}$ MEIRELLES, Hely Lopes. Op. cit., p. 44-46.
} 
aplicação ao caso concreto, enquanto essas ou bem são aplicadas em sua integralidade ou simplesmente não o são ${ }^{138}$.

Nessa esteira, aplicar indiscriminadamente certo princípio seria de fato reconhecê-lo em uma posição hierarquicamente superior, o que tende a agredir outros princípios relevantes para a maximização de direitos e interesses constitucionalmente protegidos. Na lição sobre a teoria dos princípios, Luís Roberto Barroso ensina que nenhum princípio é absoluto ${ }^{139}$ e as colisões inevitáveis devem ser solucionadas através da ponderação. Absolutamente contrária à preponderância apriorística, a ponderação é uma técnica hermenêutica que, através do sopesamento e da cedência recíproca, busca o melhor resultado possível com o mínimo sacrifício de cada dos princípios em choques.

Ora, é evidente a incompatibilidade da supremacia do interesse público com o próprio modo de aplicação dos princípios dentro da organização constitucional, haja vista que sua razão de ser é premiar a vitória do interesse público em prejuízo do interesse individual independentemente das nuances casuísticas que ensejariam a ponderação.

O argumento é autossuficiente para uma acirrada oposição ao princípio, o que não impede que outros sejam colacionados ao lado.

Sob a premissa de que todas as ordens jurídicas baseiam-se implícita ou explicitamente em alguma ideia sobre o ser humano, Daniel Sarmento parte do conceito de pessoa adotado pela Constituição de 1988 para verificar sua compatibilidade com princípio aqui aventado ${ }^{140}$. Após longa digressão sobre as teorias organicista, utilitarista e individualista ${ }^{141}$, bem

\footnotetext{
${ }^{138}$ MOREIRA NETO, Diogo Figueiredo. Op. cit., p. 82-83.

139 BARROSO, Luís Roberto. A Ordem Econômica Constitucional e os Limites à Atuação do Estatal no Controle de Preços. Op. cit., p. 47.

${ }^{140}$ SARMENTO, Daniel. Op. cit., p. 23-116.

141 Vale um esclarecimento acerca das principais características de cada uma das teorias que historicamente dominaram as ciências sociais. O organicismo concebe a sociedade como um organismo vivo, com fins e valores próprios. Cada indivíduo desempenha seu papel com o objetivo máximo de realização dos fins coletivos, dirigidos pelo Estado. O utilitarismo é uma teoria consequencialista, segundo a qual a melhor decisão para qualquer problema político-social é sempre aquela que maximiza o interesse do maior número de membros da sociedade, individualmente considerados. Por fim, o individualismo defende a integral primazia absoluta dos
} 
como suas respectivas evoluções e aplicações históricas, o ilustre professor conclui que a Constituição Federal configura-se personalista.

Com fundamento precípuo na dignidade da pessoa humana ${ }^{142}$, a norma superior do nosso ordenamento afirma a primazia desta sobre o Estado, e até mesmo sobre a sociedade, reconhecendo sua capacidade para gerir sua própria autonomia. Aqui já está evidente a inconformidade com a teoria organicista - que guarda parentesco próximo com o princípio em questão -, mas o texto constitucional tempera a afirmação evitando também que se advogue o predomínio de uma postura individualista.

Nas palavras do autor, o personalismo esculpido na Constituição tem uma "visão mais realista da autonomia" privada, reconhecendo a existência de carência humanas materiais e a importância de vínculos sociais para a sua plena realização. É nesse aspecto que o Estado deve participar, auxiliando na criação das condições adequadas para o pleno exercício da liberdade de escolha, sem que seja concebível a direção estatal aquilo que se repute mais adequado com os "valores sociais" - que aqui poderiam ser compreendidos como sinônimos de interesses públicos.

Nessa formatação constitucional, que coloca a pessoa humana no centro da ordem jurídica e reconhece direitos fundamentais, não é possível adotar um princípio que sustente a supremacia indiscriminada de interesses coletivos, sob pena de violar direitos fundamentais, corporificados, entre outros, nas garantias individuais elevadas pelo legislador à condição de cláusulas pétreas $^{143}$.

Por sua vez, Sarmento reconhece que a proteção de outros bens jurídicos de nível constitucional relacionados a interesses públicos pode justificar restrição a um direito fundamental, desde que não atinja seu

interesses privados sobre os interesses da coletividade, negando qualquer preceito de promoção da igualdade, que não aquela formal perante a lei, ou solidariedade pelo ente estatal.

${ }^{142}$ Constituição Federal de 1988, art. $1^{\circ}$ : "A República Federativa do Brasil, formada pela união indissolúvel dos Estados e Municípios e do Distrito Federal, constitui-se em Estado Democrático de Direito e tem como fundamentos: (...) III - a dignidade da pessoa humana; (...)"

${ }^{143}$ Constituição Federal de 1988, art. 60: "A Constituição poderá ser emendada mediante proposta: (...) $\S 4^{\circ}$ Não será objeto de deliberação a proposta de emenda tendente a abolir: (...) IV - os direitos e garantias individuais". 
núcleo essencial e resulte da devida ponderação de princípios. Busca-se assim, ao contrário do que resultaria do reconhecimento de uma superioridade absoluta, a utilização de fórmula jurídica capaz de evitar o esvaziamento completo dos direitos fundamentais e, ao mesmo tempo, otimizar a efetivação dos princípios conflitados.

Em linha está a doutrina de Marçal Justen Filho. Conforme mencionado anteriormente, o exímio doutrinador enxerga a concretização de direitos fundamentais - entendidos como direitos privados tão relevantes que lhes é imputada uma qualidade diferenciada - como o próprio interesse público, o que torna ilógica a restrição irrestrita e desajuizada daqueles em nome deste.

Igualmente criticada é a afirmação da supremacia prévia e incontestável de um conceito indeterminado e, portanto, naturalmente aberto. A vagueza do que venha a ser interesse público é crescente na sociedade contemporânea, cada vez mais marcada por um pluralismo que impede a percepção de uma vontade geral homogeneizada. Parece morar na maleabilidade do conceito de interesse público o seu principal perigo: tornar o princípio de sua supremacia a nova justificativa para atos autoritários.

Feitas as observações, antes do esforço de colocar em prática qualquer solução para eventuais conflitos entre interesses públicos e privados - uma das quais poderia ser a adoção do princípio em questão - é preciso confirmar um verdadeiro conflito entre eles.

Com efeito, a perfeita compreensão do que seja interesse público no contexto constitucional contemporâneo, em que a promoção dos direitos fundamentais é um dever do Estado, pode em muitas vezes apresentar um cenário de convergência ${ }^{144}$, como aponta Gustavo Binenbojm ao asseverar

\footnotetext{
${ }^{144}$ Celso Bandeira de Mello abordou a mesma questão, embora com viés diferente: “Ao se pensar em interesse público, pensa-se habitualmente, em uma categoria contraposta à de interesse privado, individual, isto é, ao interesse pessoal de cada um. (...) Deveras, na medida em quse fica com a noção altanto obscura de que transcende os interesses próprios de cada um, sem se aprofundar a compostura deste interesse tão amplo, acentua-se um falso antagonismo entre os interesses das partes e o interesses do todo. (...) Poderá haver um interesse público que seja discordante do interesse de cada um dos membros da sociedade? Evidentemente, não. Seria
} 
que "muitas vezes, a promoção do interesse público - entendido como conjunto de metas gerais da coletividade - consiste, justamente, na preservação de um direito individual, na medida do possível”145.

\subsection{O interesse público, o interesse social e o poder de controle}

Os potenciais conflitos e divergências delineados acima ganham contornos ainda mais incisivos no seio de uma sociedade de economia mista. A despeito de sua origem associada ao embrião das sociedades anônimas no século XVI, quando funcionava como uma forma de angariar recursos para a expansão colonial e comercial da Coroa holandesa, a entidade só teria seus traços jurídicos e institucionais bem definidos mais tarde.

A crise das concessões de serviços públicos e a ascensão do Welfare State, que introduziu no rol de obrigações do novo Estado Social a promoção de novos e mais serviços à população ${ }^{146}$, asfaltaram o caminho para o ressurgimento das sociedades de economia mista na primeira metade do século XIX.

Os impulsos estavam ali: (i) a Administração Pública precisava assumir a dianteira das concessões para evitar a descontinuidade da prestação de serviços essenciais e o evidente prejuízo ao interesse público; e (ii) os aspectos industriais e comerciais das atividades eram incompatíveis com a burocracia indissociável das pessoas de direito público ${ }^{147}$. A solução encontrada foi associar o capital público aos agentes econômicos privados, mantendo o regime de direito privado das companhias concessionárias compatível com sua atuação empresarial - e tomando para o Estado o

inconcebível um interesse do todo que fosse, ao mesmo tempo, contrário ao interesse de cada uma das partes que o compõem.” (BANDEIRA DE MELLO, Celso Antônio. Op. cit., p. 60).

${ }^{145}$ BINENBOJM, Gustavo. Da Supremacia do Interesse Público ao Dever de Proporcionalidade: Um Novo Paradigma para o Direito Administrativo. In: SARMENTO, Daniel (Org.), Interesses Públicos versus Interesses Privados: Desconstruindo o Princípio da Supremacia do Interesse Público. Rio de Janeiro: Lumen Iuris, pp. 117-169, 2005.

${ }^{146}$ LIMA, Paulo B. de Araújo. Op. cit., p. 21-25.

${ }^{147}$ CARVALHO FILHO, José dos Santos. Op. cit., p. 489. 
controle da sua gestão. O meio para tanto, embora caído no ostracismo desde o advento do Estado Liberal, já existia.

Sem muitas dúvidas, se identifica a partir dessa segunda fase um interesse público subjacente à atuação direta estatal por meio da sociedade de economia. A justificativa para sua existência deixou de ser o enriquecimento estatal e passou a ser a promoção do interesse público, o que se alinha com a função que as ordens constitucionais mais modernas inclusive a brasileira - deram ao ente estatal.

Como já visto no tópico sobre sua origem, o fenômeno e a evolução não são peculiares à história brasileira, mas refletem o que aconteceu ao redor do mundo ocidental no que se refere à intervenção estatal e à utilização das sociedades de economia mista.

Ao que pese o interesse público emprestar à participação estatal sua razão fundamental de existência e essa, por sua vez, ser característica distintiva do ente societário, não se pode olvidar que a sociedade de economia mista sempre esteve primordialmente submetida a regras de direito privado, especialmente aquelas aplicáveis às sociedades anônimas $^{148}$.

Na qualidade de um sistema flexível, que permite a captação de recursos privados para realização de atividades de interesse público, a sociedade de economia mista é a forma encontrada para institucionalizar a colaboração entre os interesses do Estado - essencialmente públicos - e os interesses privados dos seus demais acionistas.

Esse é o ponto crucial das sociedades de economia mista: a participação do Estado no capital social e na gestão indica a existência de um interesse público, do qual não pode a Administração Pública dispor,

\footnotetext{
148 "Embora elas tenham personalidade dessa natureza, o regime jurídico é hibrido, porque o direito privado é parcialmente derrogado pelo direito público. Mas, falando-se em personalidade de direito privado, tem-se a vantagem de destacar o fato de que ficam espancadas quaisquer dúvidas quanto ao direito a elas aplicável: será sempre o direito privado, a não se que esteja na presença de norma expressa de direito público.” (DI PIETRO, Maria Sylvia Zanella. Op. cit., p. 506).
} 
cabendo-a tão somente a sua promoção e proteção ${ }^{149}$. Por sua vez, ao aceitar o ingresso de investidores particulares na sociedade, o Estado reconhece o resultado econômico - lucro - como objetivo da atividade empresarial.

Resulta daí uma pergunta simples de ser feita e difícil de ser respondida: é possível conciliar o interesse público indispensável à criação das sociedades de economia mista com os interesses privados perseguidos pelos demais acionistas?

Primeiramente, parece-nos indubitável que a sociedade de economia mista é constituída para alcançar fins de interesse público. A própria Lei das Sociedades Anônimas., em seu artigo 238, estabelece que a pessoa jurídica que controla a sociedade de economia mista poderá orientá-la para atender o interesse público que justificou sua criação ${ }^{150}$. Nem poderia ser diferente, tendo em vista a necessária reversão de bens públicos ao capital social da sociedade formada. Qualquer intenção do poder público que destoe desse comportamento se mostra incompatível com a ordem econômica estabelecida pela Constituição Federal de 1988, sobretudo com o artigo 173 que regula a participação direta do Estado na exploração de atividades econômicas, e configuraria desvio de finalidade.

Contudo, ainda que dessa primeira característica decorra a aplicação de diversas regras de direito público ${ }^{151}$, não se pode cogitar a entrega de

\footnotetext{
149 "A indisponibilidade dos interesses públicos significa que, sendo interesses qualificados como próprios da coletividade - internos ao setor público, não se encontram à livre disposição de quem quer seja, por inapropriáveis. O próprio órgão administrativo que os representa não tem disponibilidade sobre eles, no sentido de que lhe incumbe apenas curá-los - o que também é dever - na estrita conformidade do que predispuser a intentio legis." (BANDEIRA DE MELLO, Celso Antônio. Op. cit., p. 76). No mesmo sentido: “(...) a Administração não pode desistir de agir para a satisfação dos interesses que lhe foram confiados, embora isso não a tolha de escolher, respeitados os limites da própria lei e do Direito, como, quando e de que modo realizá-los - vale dizer, as opções discricionárias para a escolha dos meios e das oportunidades para lograr os melhores resultados - ou seja praticar a boa administração." (MOREIRA NETO, Diogo de Figueiredo. Curso de Direito Administrativo. Op. cit., p. 98).

${ }^{150}$ BANDEIRA DE MELLO, Celso Antônio. Op. cit., p . 198.

151 "O arrolamento destes vários dispositivos (de resto, todos eles aplicáveis também às autarquias e fundações públicas) demonstra que o regime das sociedades de economia mista e empresas públicas, sejam elas prestadores de serviços públicos (obras públicas e demais atividades de tipologia pública) ou exploradoras de atividade econômica, já por força destas normas categoricamente expressas na Constituição, não é o mesmo das empresas privadas em geral." (Ibid., p. 207).
} 
uma carta branca ao Estado, na qualidade de acionista controlador das sociedades de economia mista, para agir exclusivamente em nome do interesse público, sob pena de violação dos direitos dos acionistas minoritários. Nesse sentido é que o dispositivo da Lei da Sociedades Anônimas, ao determinar que o interesse público poderá ser perseguido pela sociedade, faz a ressalva "sem prejuízo dos deveres $e$ responsabilidades do acionista controlador", os quais encontram-se devidamente definidos em seu artigo 116.

Ao dar a roupagem de sociedade anônima e submeter a sociedade de economia mista às normas de direito privado - ainda que sujeitas a derrogações pela via legal -, o legislador ordinário e o legislador constituinte expuseram sua intenção de criar um veiculo de atuação estatal direta dotado da flexibilidade e celeridade necessárias à execução de atividade econômica em regime de mercado.

A contrapartida à adoção desse regime é o reconhecimento de que, assim como as demais sociedades empresariais, a sociedade de economia de mista tem como função produzir lucros para seus acionistas, inclusive o Estado $^{152}$.

Sendo assim, não é descabido - muito pelo contrário - identificar uma contradição potencial entre a expectativa de resultado e maximização do valor do investimento - corporificação dos interesses dos demais acionistas - e a utilização da companhia como instrumento de políticas de governo que visam atender ao "interesse público".

Para Nelson Eizirik, o ponto é determinante à resposta da pergunta formulada anteriormente, tendo em vista que "é essa equação que viabiliza a existência da sociedade de economia mista; se não for possível a conciliação da atividade pública com a produção de resultado econômicos, não se justifica a sua criação."153

\footnotetext{
152 "A segunda relaciona-se com as sociedades de economia mista. Se o Estado recorrer aos particulares para captar recursos para a exploração de uma atividade empresarial, acenando com o retorno de lucros, ser-lhe-á vedado ignorar os interesses dos particulares aos quais se associou." (JUSTEN FILHO, Marçal. Op. cit., p. 266).

${ }^{153}$ EIZIRIK, Nelson. Op. cit., p. 313.
} 
Se é verdade que o Estado ao admitir a associação de investidores privados reconhece que a sociedade estará destinada à busca pelo lucro, também é verdade que o investidor privado ao decidir participar de uma sociedade de economia mista reconhece que há um interesse público intrínseco à sua constituição, o qual deverá orientar a conduta de seu acionista controlador.

Esse fato exacerba no tipo societário a importância de um estatuto que descreva com precisão, transparência e completude o objeto social da companhia, não só no que tange as atividades empresariais e econômicas desenvolvidas, mas especialmente o interesse público que motivou sua criação, isto é, as políticas econômicas e sociais que o Estado pretende por em prática. ${ }^{154}$

A vinculação do controlador e da administração ao objeto social da companhia é uma característica essencial das sociedades anônimas, integralmente aplicável à sociedade de economia mista. O poder de controle, que conforme o artigo 116 da Lei das S.A. deve ser exercido em prol dos interesses sociais - de certa forma, corporificados no objeto social -, configura um direito função ${ }^{155}$, sendo legalmente vedado o abuso em detrimento dos interesses dos acionistas minoritários ${ }^{156}$.

A diferença (se é que se deve chamar assim) é que nas sociedades de economia mista o objeto social abrange não só os interesses empresariais, mas também o interesse público que justificou sua criação, de modo que o abuso do poder de controle somente se afigura caso o ente estatal controlador oriente a atuação da companhia para fora desse limite consolidado $^{157}$.

\footnotetext{
${ }^{154}$ Ibid., p. 308.

${ }^{155}$ Ibid., p. 315.

${ }_{157}^{156}$ JUSTEN FILHO, Marçal. Op. cit., p. 264-265.

157 "Na sociedade de economia mista o Estado persegue objetivos de interesse público, podendo orientá-la legitimamente para o seu atendimento, mesmo em detrimento dos interesses dos acionistas minoritários, caso em que não se caracterizará abuso de poder de controle." (EIZIRIK, Nelson. Op. cit., p. 314).
} 
Por mais que um objeto social bem definido e devidamente sustentado na lei autorizadora certamente seja um argumento para reduzir a força dos conflitos e dar previsibilidade à forma como a sociedade de economia mista será dirigida, ele não evita a contradição intrínseca ao tipo.

Reconhecendo a dificuldade de conciliar fins tão distintos em um só objeto social, compartilhado por acionistas que naturalmente possuem interesses distintos, alguns autores aventam a possibilidade da implementação de soluções específicas ao tipo societário.

Eizirik, por exemplo, aventa a criação de uma regra de governança corporativa, mediante a qual a sociedade seja obrigada a reconhecer e quantificar os custos incorridos com a implementação das políticas públicas de interesse do Estado que sejam contrários ao objetivo de maximização dos custos. Uma vez reconhecidos e quantificados, tais custos seriam arcados somente pelo acionista controlador, evitando assim o impacto no resultado econômico auferido pelos demais investidores.

Embora a solução customizada pareça resolver o problema, sua implementação requer que alguns obstáculos sejam ultrapassados. Inicialmente, não aparenta ser razoável dentro da legislação atual o ressarcimento pelo Estado dos gastos incorridos na perseguição do interesse público, dado que o objetivo precípuo e a razão de sua própria existência da sociedade é a referida perseguição. Na esteira do que o próprio Eizirik afirma, ou bem se reconhece que a sociedade poderá em determinadas situações ceder ao interesse público e abster-se de tomar a decisão mais alinhada à maximização dos lucros - sem que o Estado acionista controlador tenha que indenizar os custos sociais daí decorrentes -, ou bem se estará aceitando a completa implosão dos fundamentos existenciais da entidade.

Ainda que se entenda possível a adoção da estrutura proposta, sua concretização esbarraria na missão inglória de definir dentro do escopo da atuação empresarial quais foram os atos motivados exclusivamente por interesse público - o que perpassaria novamente a própria definição 
nebulosa do termo - e qual foi o custo líquido incorrido, caso em que se poderia argumentar, por exemplo, que houve algum resultado positivo para a sociedade, ainda que não maximizado, capaz de compensar uma parte dos custos.

Com o devido respeito à opção sugerida pelo autor, a complexidade refletida no número de premissas que teriam que ser adotadas, por vezes mais subjetivas que objetivas, nos leva a pensar que a apuração acabaria sendo demasiadamente custosa, demorada e, muito provavelmente, fruto de discordâncias sem fim entre acionista controlador e acionista minoritário.

Restando deficiente a propositura de soluções de caráter indenizatório e aparentemente intransponível a contradição eventual entre a realização do interesse público e a maximização dos lucros da sociedade de economia, talvez o ponto de ajuste da conduta do acionista controlador e o fator determinante na direção da entidade encontre fundamento fora da interpretação acerca da superioridade de um ou de outro interesse.

Sobre o tópico vale ainda elucidar um equívoco comum. Ao contrário do que pode parecer em discursos de governantes e partidários da atuação direta estatal, não são quaisquer políticas públicas e sociais de interesse público que podem ser executadas ou incentivadas por uma sociedade de economia mista. Pelo contrário, do exposto acima, se depreende que as políticas públicas e sociais aceitáveis são exclusivamente aquelas descritas no objeto social, devidamente definido por lei autorizadora.

Tome-se, por exemplo, a Petrobras, sociedade de economia mista de capital aberto que tem como objeto a exploração de petróleo e derivados. Ora, o interesse público que levou a sua constituição e que vincula sua atuação é o desenvolvimento do setor petroquímico através da exploração de petróleo. Portanto, não se pode cogitar de objetivos complementares, seja a geração de empregos, a promoção do desenvolvimento de determinadas regiões do país, o fomento de uma indústria, o controle da 
inflação mediante congelamento de $\operatorname{preços}^{158}$, dentre outros, sob pena de configurar o abuso de controle.

\subsection{A busca pelo lucro, o princípio da eficiência e a concorrência}

Em perfeito alinhamento com o artigo $173, \S 1^{\circ}$, da Constituição, que elegeu as sociedades de economia mista como um dos instrumentos disponíveis para atuação direta do Estado no domínio econômico, a definição legal do tipo societário estabeleceu que seu objetivo é o desempenho de atividades econômicas (aqui em seu conceito amplo, incluindo a prestação de serviços públicos).

O fim empresarial, próprio da iniciativa privada, e a opção pela "associação com capitais privados" eliminam qualquer dúvida sobre a necessidade da busca pelo resultado positivo - lucro - nas sociedades de economia mista, dando a certeza de que Marçal Justen Filho está correto ao afirmar que "aplicação pelo Estado de recursos públicos numa empresa dotada de personalidade jurídica de direito privado não se destina, em princípio, a estabelecer uma alternativa não lucrativa para a atuação empresarial",159.

Disse-se "eliminam qualquer dúvida", pois não se deveria nem cogitar a possibilidade de discussão sobre a questão. O dever de buscar a eficiência operacional não é uma peculiaridade da sociedade de economia mista, pelo contrário, constitui um dever de toda organização estatal, típico do regime republicano e atrelado ao princípio da eficiência ${ }^{160}$.

Por sua vez, a ressalva "em princípio" deve-se a possibilidade de se eleger liberalidades que reduzam a eficiência econômica em favor de

\footnotetext{
${ }^{158}$ FRAGA, Armínio; TRINDADE, Marcelo. Sobre a Governança das Estatais. Estado de São Paulo, São Paulo, p. 10, 27 nov. 2014.

159 JUSTEN FILHO, Marçal. Op. cit., p. 266.

160 “O núcleo do princípio é a procura de produtividade e economicidade e, o que é mais importante, a exigência de reduzir os desperdícios de dinheiro público, o que impõe a execução dos serviços públicos com presteza, perfeição e rendimento funcional." (CARVALHO FILHO, José dos Santos. Op. cit., p. 29).
} 
determinados grupos, mediante autorização legislativa que seja compatível com a Constituição.

Fato é que, em situações gerais, o modus operandi padrão das entidades públicas é guiado pela redução dos gastos ao mínimo possível e a ampliação das vantagens ao máximo possível ${ }^{161}$, desde que respeitado o princípio da legalidade e sem prejuízo da realização dos deveres administrativos que cabem ao ente estatal ${ }^{162}$. Chama-se essa obrigação de "princípio da eficiência”, um corolário do "princípio da boa administração".

A maior exposição que o tema tem nas sociedades de economia mista - especialmente quando comparadas às empresas públicas que, por exemplo, também tem fim empresarial - deve-se à participação de particulares interessados precipuamente em ver o retorno dos seus investimentos. A personalidade e o regime jurídico (preponderantemente) de direito privado, assim como a forma de sociedade anônima, dão ao ente estatal uma entidade dotada das características necessárias à realização de atividades empresariais, típicas das pessoas jurídicas de direito privado, mas em contrapartida exigem que se atente para a lucratividade da atividade $^{163}$, enquanto acionista controlador.

Ao estabelecer que atividades econômicas são exercidas pelo Estado através de sociedades de economia ou empresas públicas e sujeitá-las ao mesmo regime jurídico das empresas privadas (art. 173, caput, $\S 1^{\circ}$ e $\S 1^{\circ}$, inciso III), o legislador constituinte buscou dois objetivos simultâneo: criar um instrumento adequado ao exercício da atividade empresarial pelo Estado

\footnotetext{
${ }^{161}$ JUSTEN FILHO, Marçal. Op. cit., p. 266 e 447.

${ }^{162}$ Bandeira de Mello faz a ressalva para impedir o raciocínio de que a busca pela eficiência poderia se desvincular do dever administrativo por excelência. Para o autor, o princípio consiste em uma faceta de outro maior, o princípio da boa administração, segundo o qual a atividade administrativa deve ser realizada do modo mais congruente, oportuno e adequado aos fins a serem alcançados. (BANDEIRA DE MELLO, Celso Antônio. Op. cit., p. 125)

163 "Por definição, sociedades mistas são as que conjugam capitais governamentais e particulares. Destarte, a razão vital desse gênero de pessoa é a viabilidade de desenvolver-se eficazmente atividade pública - e daí a participação do Estado, interesse nessa atividade - e, ao mesmo tempo, produzir saldos econômicas apropriáveis, o que enseja a afluência de capitais privados. Sem essa equação, a sociedade de economia mista inexistiria. Portanto, é pressuposto lógico - e por isso jurídico, visto a existência da sociedade mista haver sido prevista constitucional e legalmente - de sua constituição o regime lucrativo, ainda quando se trata de exploradora de serviço público." (SUNDFELD, Carlos Ari. Entidades Administrativas e Noção de Lucro. Revista Trimestral de Direito Público, São Paulo, n. 6, pp. 269-276, 1994, p. 273-275).
} 
e submeter tal instrumento às mesmas regras aplicáveis aos seus "competidores".

A associação de capitais públicos e privados daí resultante é o ponto de equilíbrio entre o tipo societário misto e a atividade econômica que se propõe a realizar, fornecendo um modelo viável para a atuação direta estatal e ao mesmo tempo requerendo uma grande atenção a como manejar os interesses quase sempre contrapostos.

A tentativa de organizar a entidade em torno dessas funções permitir a atuação empresarial do Estado sem deixar de buscar resultados atrativos para o investidor privado - foi impressa no DNA das sociedades de economia mista desde o estabelecimento das primeiras no país. Vale transcrever trecho elucidativo do discurso de Guilherme Guinle, proferido na Assembleia Geral de Constituição da Companhia Siderúrgica Nacional CSN, uma das primeiras companhias a serem constituídas na segunda fase da entidade no país:

"A preocupação dominante foi a de estabelecer uma empresa baseada numa finança sãa, sob os moldes de uma organização industrial capaz de remunerar os capitais nela empenhados."164

Não é preciso muito esforço para enxergar que a intenção jamais foi apenas promover o interesse público, independentemente do resultado da atividade. Muito pelo contrário, nas palavras do próprio, a "preocupação dominante" com a criação da sociedade consistia em como criar uma estrutura "capaz de remunerar [todos] os capitais nela empenhados".

$\mathrm{O}$ argumento parece óbvio - e de fato é -, mas mesmo assim é preciso fazê-lo: se a atividade desenvolvida não pode dar resultado positivo e requer tão somente o dispêndio de recursos para atingir um interesse público legítimo, ela não deve ser realizada através de uma sociedade de economia mista, devendo ser escolhido outro instrumento à disposição do ente estatal.

\footnotetext{
${ }^{164}$ VENÂNCIO FILHO, Alberto. Sociedades de Economia Mista. In: LAMY FILHO, Alfredo; PEDREIRA, José Luiz Bulhões (Coord.). Direito das Companhias, vol. 2, $1^{\text {a }}$ ed.. Rio de Janeiro: Forense, 2009, p. 1908.
} 
Mas a necessária busca pelo lucro não se fundamenta apenas no fim empresarial e na associação com capitais privados. A livre concorrência, princípio da atual ordem econômica ${ }^{165}$ previsto no artigo 170 , inciso IV, da Constituição Federal ${ }^{166}$, expõe que as atividades econômicas empresariais devem ser exercidas em regime de competição entre os produtores de bens e prestadores de serviços no mercado.

Conforme o parágrafo $\S 4^{\circ}$ do artigo 173 , também da Constituição Federal de $1988^{167}$, é dever do Estado repelir o uso incorreto do poder econômico, isto é, o abuso de poder que leve à "dominação de mercados, à eliminação da concorrência e ao aumento arbitrário dos lucros" ${ }^{\text {168 }}$.

Com efeito, a execução da atividade econômica em regime deficitário, a partir da prática deliberada de preços abaixo do valor de custo do bem ou serviço devidamente acrescido de uma rentabilidade mínima exigida para o risco da atividade em questão, também atenta contra o modelo de concorrência, configurando o chamado dumping. Tal situação impede a plena competição com a empresa que atua de forma deficitária deliberadamente.

Portanto, seja porque foge ao objeto social e caracteriza abuso de poder de controle - como demonstrado anteriormente -, seja porque viola diretamente o princípio da livre concorrência, o Estado não pode, por exemplo, congelar preços, reduzindo a margem de resultado da atividade e incorrendo em prejuízo, sob o pretexto de estar protegendo o interesse público consistente em uma inflação mais baixa ${ }^{169}$.

\footnotetext{
165 GRAU, Eros. Op. cit., p. 206.

166 Constituição Federal de 1988, art. 170: “A ordem econômica, fundada na valorização do trabalho humano e na livre iniciativa, tem por fim assegurar a todos existência digna, conforme os ditames da justiça social, observados os seguintes princípios: (...) IV - livre concorrência; (...)"

${ }^{167}$ Constituição Federal de 1988, art. 173: "Ressalvados os casos previstos nesta Constituição, a exploração direta de atividade econômica pelo Estado só será permitida quando necessária aos imperativos da segurança nacional ou a relevante interesse coletivo, conforme definidos em lei. (...) $\$ 4^{\circ}$ - A lei reprimirá o abuso do poder econômico que vise à dominação dos mercados, à eliminação da concorrência e ao aumento arbitrário dos lucros."

${ }^{168}$ BANDEIRA DE MELLO, Celso Antônio. Op. cit., p. 817.

${ }^{169}$ EIZIRIK, Nelson. Op. cit., p. 315.
} 


\section{CONCLUSÃO}

O objetivo dessa monografia é expor de forma estruturada um tema que permeia a maioria das discussões políticas e econômicas de nossa sociedade: a atuação estatal no domínio econômico como empresário, especialmente através de sociedades de economia mista.

Com fundamento na legislação constitucional e infraconstitucional, tentamos aqui tornar o debate menos raso dando aos leitores um arcabouço teórico sobre a questão ao abordar a formação político-econômica do Estado brasileiro, o conceito de sociedade de economia mista e os conflitos potenciais que a utilização do tipo societário inevitavelmente acarreta.

O resumido histórico sobre a evolução do pensamento políticoeconômico no mundo revelou uma divisão temporal em três grandes fases o Estado Liberal, o Estado-intervencionista ${ }^{170}$ e o atual Estado-regulador-, expondo um movimento pendular da relação entre o Estado e economia ao longo dos séculos, bem como os fatores que impulsionaram o movimento em uma ou outra direção em cada época.

Ainda na primeira parte chegamos à discussão sobre a justificativa de toda e qualquer atuação do Estado brasileiro contemporâneo e à apresentação dos meios que lhe foram reservados para atuar no domínio econômico. Traçamos algumas considerações sobre o interesse público, um conceito jurídico de definição indeterminada que representa o norte e também o limite da atuação estatal no atual modelo constitucional e, em seguida, apresentamos as características gerais das modalidades de fomento, regulação e atuação direta, todas legítimas formas de intervenção no domínio econômico reservadas ao atual Estado pela Constituição Federal.

A segunda parte apresentou especificamente a sociedade de economia mista como instrumento de atuação direta, examinando seu

\footnotetext{
${ }^{170}$ Embora a contraposição seja costumeiramente feita com o regime socialista, tivemos poucos casos expressivos onde tal tipo de ordem econômica foi adotada. Por sua vez, são diversos os modelos e os graus de intervencionismo adotados por inúmeros governos ao longo do século XX.
} 
conceito jurídico e as peculiaridades que lhe diferenciam das demais sociedades anônimas, notadamente a participação do erário em seu capital social e da Administração Pública na sua gestão.

Após a exposição das razões do Estado contemporâneo e da sociedade de economia mista como um instrumento relevante para a execução dessas "razões", a terceira parte encarregou-se dos temas conflituosos oriundos da problemática, porém necessária, relação entre o interesse público (primário) e o interesse social no seio das sociedades de economia mista.

Durante a exposição ordenada da função estatal e do instrumento sociedade de economia mista a intenção sempre foi que estivessem constantemente implícitas as perguntas sobre sua validade e eficiência, as quais podem ser simplificadas em: ( $i$ ) em que situação seria possível criar e manter uma sociedade de economia mista? e (ii) faz sentido utilizar esse instrumento tendo em vista os inúmeros problemas que lhe são inevitáveis?

Para responder às perguntas é preciso retomar os pontos apresentados e identificar as premissas exigidas pelo ordenamento jurídico brasileiro para que seja permitida a atuação direta do Estado no domínio econômico através da sociedade de economia mista.

A primeira delas tem natureza constitucional e consiste na existência de interesse coletivo relevante na execução da atividade econômica que será objeto da sociedade de economia mista. Como visto, qualquer atuação estatal requer a presença de interesse coletivo (compreendido como sinônimo do interesse público) sob pena de desvio de finalidade. Ao enfatizar essa necessidade e utilizar o termo "relevante" para qualificá-la, a intenção do constituinte foi restringir substancialmente as situações em que seria possível ao Estado assumir sua feição de empresário sob o pretexto de promover um "interesse supraindividual, de toda a sociedade".

Alinhado com os ideais político-econômicos que deram origem à uma Constituição personalista, a segunda premissa consiste na afirmação de que a atuação direta estatal tem um caráter subsidiário à iniciativa privada. 
Explica-se: ainda que exista um interesse público na execução da atividade econômica pelo Estado, esse somente poderá executá-la diretamente caso a iniciativa privada falhe na realização e na medida de tais falhas. Trata-se do princípio da atuação residual, defendido por grande parte da doutrina e oriundo da orientação geral que coloca a iniciativa privada na função de ator principal da ordem econômica.

A criação de uma sociedade de economia mista exige ainda a verificação de uma terceira premissa. A participação de investidores privados na formação do capital social requer que a atividade desempenhada seja lucrativa e ofereça um retorno adequado para o investimento realizado e o risco incorrido. A sociedade de economia mista nasce com a intenção de ter suas finanças sãs e ajustadas de modo a atender os interesses privados. Ao contrário do que discursos politizados e ideológicos podem fazer parecer, não se trata de um instrumento potencialmente deficitário exclusivamente a serviço da promoção do interesse público.

As três premissas jurídicas exigidas pelo constituinte e o legislador ordinário já são suficientes para tornar complexa a tentativa de encontrar uma atividade econômica que possa ser exercida pelo Estado com fundamento em interesse coletivo relevante, conforme a terceira opção do artigo 173 da Constituição Federal.

Essa procura fica ainda mais difícil quando se acrescenta à avaliação uma premissa básica de natureza econômica: atividades lucrativas e com retorno adequado a risco serão sempre do interesse da iniciativa privada.

O conceito por trás desse "princípio econômico" nada mais é do que uma avaliação dos custos e dos beneficio associados à execução de qualquer atividade, inclusive a empresária. Caso o resultado dessa pesagem seja positivo, ou seja, os benefícios sejam superiores aos custos em determinada medida, a atividade em princípio será realizada por agentes privados. 
Chegamos assim a uma contradição que nos parece intrínseca ao tipo societário e dele inafastável. Inobstante a existência de interesse público relevante, se a atividade for lucrativa será executada pela iniciativa privada, não sendo cabível a atuação direta estatal em função do princípio da subsidiariedade; por outro lado, se a atividade não for lucrativa, mas houver interesse público relevante na sua execução, o instrumento a ser utilizado não deve ser a sociedade de economia mista, haja vista que não será possível atender aos interesses privados dos demais acionistas particulares corporificados essencialmente na obtenção de lucro. Esse raciocínio puro nos levaria à concluir que a Constituição criara uma hipótese impossível, o que, contudo, não nos parece verdadeiro.

Nesse sentido, em que situação seria cabível a criação de uma sociedade de economia mista?

Sendo certo que se as quatro premissas acima forem verdadeiras cria-se uma circularidade que impossibilita a utilização do instrumento, este somente nos parece cabível no momento em que não se verifica ao menos uma delas.

Assumindo que as três premissas jurídicas são impositivas e necessariamente precisam estar presentes, resta a possibilidade do instrumento ser válido quando a premissa de caráter econômico não se verificar, isto é, quando uma atividade lucrativa de interesse público relevante não estiver sendo executada pela iniciativa privada por qualquer razão.

Verificado esse cenário, caberia ao Estado atuar como fomentador da atividade em questão, sendo perfeitamente aceitável a utilização da sociedade de economia mista como instrumento de atuação.

Com exceção do Banco do Brasil, surgido em época pretérita, as demais sociedades de economia mista que surgiram no país no século $\mathrm{XX}$, especialmente durante o Governo Vargas, foram dentro desse cenário em que, embora consistissem em atividades econômicas rentáveis, o início do seu desenvolvimento em solo nacional requereu o financiamento e 
participação do Estado. Foi assim com a Companhia Nacional de Siderurgia - CSN, com a Petrobras, com a Vale do Rio Doce (hoje somente Vale), com a Eletrobrás e diversas outras companhias da categoria chamada de indústrias de base, a qual inegavelmente envolve atividades econômicas de relevante interesse público.

Contudo, ao dar também à atuação direta estatal um caráter de fomento, implicitamente se adota um critério temporal para a validação do instrumento. A partir do momento que a atividade econômica exercida pela sociedade de economia mista também estiver sendo desenvolvida por agentes exclusivamente privados, sem quaisquer falhas na atenção do interesse público relevante que motivou a primária atuação estatal, poderia o Estado permanecer como acionista controlador da sociedade de economia mista?

Por trás da questão está a necessária justificativa da atuação estatal, sendo possível argumentar que, uma vez extintos os fatores que motivaram a atuação direta do Estado, a continuidade da participação estatal no seio societário não seria cabível.

Além da ausência de justificativa para permanecer como empresário, em função da aplicação do princípio da subsidiariedade, a defesa do ponto de vista acima exposto também parece encontrar fundamento no princípio da eficiência.

Sendo certo que os recursos do Estado são finitos e que a função da Administração Pública é "fazer mais, com menos", uma vez fomentada determinada atividade econômica de interesse público relevante a interpretação dos princípios econômicos constitucionais nos leva a crer que os recursos públicos ali investidos devem ser direcionados para outras razões, onde não haja interesse de execução pela iniciativa privada.

Essa ideia perpassa a noção de que a escolha do agente privado como principal promotor de atividades econômicas pelo legislador constituinte não foi ocasional, mas resultou da concepção de que a 
iniciativa privada é mais apta a exercer a função empresária do que o ente público estatal.

Encontrada as situações em que é possível criar e manter uma sociedade de economia mista, a resposta da segunda pergunta se vê bastante facilitada.

Com efeito, o raciocínio cursado até aqui nos fazer crer que a utilização de sociedades de economia mista, com todos os problemas que lhe são inerentes, só faz sentido naquelas situações em que o Estado pretende atuar como fomentador de uma atividade econômica lucrativa de interesse público relevante que não está sendo executada pela iniciativa privada e, quando possível, retirar-se da função de empresário, abrindo espaços para os agentes particulares. Nesse caso, os problemas e as contradições inerentes ao tipo societário seriam aceitáveis durante um determinado espaço de tempo em nome da atenção ao interesse público relevante que não está sendo atendido integral ou adequadamente pela iniciativa privada. Em qualquer outra situação, a sociedade de economia mista deveria ser preterida a outros instrumentos de intervenção à disposição do Estado. 


\section{BIBLIOGRAFIA}

ARAGÃO, Alexandre Santos de. Agências Reguladoras e a Evolução do Direito Administrativo Econômico. 2a ed., Rio de Janeiro: Forense, 2006.

BANDEIRA DE MELLO, Celso Antonio. Curso de Direito Administrativo, 30 ed., São Paulo: Malheiros, 2013.

BARROS, Alberto Moniz da Rocha. O Poder Econômico do Estado Contemporâneo e seus Reflexos no Direito. São Paulo: Revista dos Tribunais, 1953.

BARROSO, Luís Roberto. A Ordem Econômica Constitucional e os Limites à Atuação do Estatal no Controle de Preços. In: ARAGÃO, Alexandre dos Santos de (Coord.). Revista de Direito da Associação de Procuradores do Novo Estado do Rio de Janeiro: Direito da Regulação, v. XI, Rio de Janeiro: Lumen Iuris, 2002.

\section{Curso de Direito Constitucional Contemporâneo: os} conceitos fundamentais e a construção do novo modelo, $4^{a}$ ed., São Paulo: Saraiva, 2013.

- Intervenção do Domínio Econômico - Sociedade de Economia Mista - Abuso do Poder Econômico. Revista de Direito Administrativo, Rio de Janeiro: Renovar, v. 212, 1998.

BERCOVICI, Gilberto. Atuação do Estado no Domínio Econômico e Sistema Financeiro Nacional. Inexigibilidade de Licitação em Incorporação ou em Alienação do Controle de uma Sociedade de Economia Mista por outra Sociedade de Economia Mista. Revista de 
Direito Mercantil, Industrial, Econômico e Financeiro, São Paulo, n. 148, p. 233-270, 2007.

Direito Econômico do Petróleo e dos Recursos Minerais, $1^{\mathrm{a}}$ ed.. São Paulo: Quartier Latin, 2011.

BINENBOJM, Gustavo. Da Supremacia do Interesse Público ao Dever de Proporcionalidade: Um Novo Paradigma para o Direito Administrativo. In: SARMENTO, Daniel (Org.), Interesses Públicos versus Interesses Privados: Desconstruindo o Princípio da Supremacia do Interesse Público. Rio de Janeiro: Lumen Iuris, pp. 117-169, 2005.

BORBA, José Edwaldo Tavares. Direito Societário. $13^{\mathrm{a}}$ ed., São Paulo: Renovar, 2012.

Sociedade de Economia Mista e Privatização. Rio de Janeiro:

Lumen Juris, 1997.

CARVAlHO FILHO, José dos Santos. Manual de Direito Administrativo. $25^{\mathrm{a}}$ ed.. São Paulo: Atlas, 2012.

COMPARATO, Fábio Konder. Sociedade de Economia Mista Transformada em Sociedade Anônima Ordinária - Inconstitucionalidade. Revista Trimestral de Direito Público, São Paulo, n. 25, pp. 61-68, 1999.

DALLARI, Dalmo de Abreu. Elementos da Teoria Geral do Estado. São Paulo: Saraiva, 2003.

DI PIETRO, Maria Sylvia Zanella. Direito Administrativo. $25^{\mathrm{a}}$ ed., São Paulo: Atlas, 2012. 
EIZIRIK, Nelson. A Lei das S/A Comentada, vol. III. $1^{\text {a }}$ ed.. São Paulo: Quartier Latin, 2011.

FERRAZ JUNIOR, Tércio Sampaio. Interesse Público. Revista do Ministério Público do Trabalho da $2^{\mathrm{a}}$ Região. Disponível em: http://www.prt2.gov.br/revl.shtml. Acesso em 15 mai. 2015.

FERREIRA, Waldemar. A Sociedade de Economia Mista em seu Aspecto Contemporâneo. São Paulo: Max Limonad, 1956.

FRAGA, Armínio; TRINDADE, Marcelo. Sobre a Governança das Estatais. Estado de São Paulo, São Paulo, p. 10, 27 nov. 2014.

GABARDA, Emerson. Interesse Público e Subsidiariedade. Belo Horizonte: Fórum, 2009.

GRAU, Eros. A Ordem Econômica na Constituição de 1988, 15ª ed., revista e atualizada, São Paulo: Malheiros, 2012.

Prestação de Serviços Públicos e Administração Indireta: Concessão e Permissão de Serviço Público, Autarquias, Sociedades de Economia Mista, Empresas Públicas, Fundações Governamentais, 2a ed., São Paulo: Revista dos Tribunais, 1987, pp.97-98.

HAYEK, Friedrich. Law, Legislation and Liberty, v. II. Chicago: The University of Chicago Press, 1976.

JUSTEN FILHO, Marçal. Curso de Direito Administrativo, $8^{\mathrm{a}}$ ed., rev. e ampl.. Belo Horizonte: Editora Fórum, 2012. 
LIMA, Paulo B. de Araújo. Sociedade de Economia Mista e a Lei das S.A.. Rio de Janeiro: IBMEC, 1980.

MAIA, Bruna. Entre Dois Públicos - A Influência do Governo sobre suas Controladas Incomoda Investidores e Levante o Debate: É Possível Conciliar os Papeis de Estatal e Companhia Aberta?. Revista Capital Aberto, n. 93, maio, 2011.

MEIRELLES, Hely Lopes. Direito Administrativo Brasileiro, 39ª ed.. São Paulo: Malheiros, 2013.

MENDONÇA, José Vicente Santos de. Uma teoria do Fomento Público: Critérios em Prol de um Fomento Público Democrática, Eficiente e NãoPaternalista. Revista de Direito da Procuradoria Geral, v. 65, Rio de Janeiro, 2010.

MOREIRA NETO, Diogo de Figueiredo. Curso de Direito Administrativo, $15^{\mathrm{a}}$ ed., Rio de Janeiro: Forense, 2011.

Ordem Econômica e Desenvolvimento na Constituição de 1988. Revista de Direito da Procuradoria Geral do Estado do Rio de Janeiro, Rio de Janeiro, v. 42, 1990, pp. 57-67.

OSÓRIO, Fabio Medina. Existe uma Supremacia do Interesse Público sobre o Privado no Direito Administrativo Brasileiro?. Revista de Direito Administrativo, n. 220, Renovar, 2000.

PAIVA, Alfredo de Almeida. As Sociedades de Economia Mista e as Empresas Públicas como Instrumentos Jurídicos a Serviço do Estado. Revista de Direito Administrativo, Rio de Janeiro, seleção histórica, 19451995. 
PENTEADO, Mauro. As Sociedades de Economia Mista e as Empresas Estatais Perante a Constituição de 1988. Revista de Informação Legislativa, Brasília, a. 26, n. 102, pp. 49-68, 1989.

PINHEIRO, Armando Castelar. A Experiência Brasileira de Privatização: o que vem a seguir?. Rio de Janeiro: BNDES, 2000. Disponível em <http://www.bndes.gov.br/SiteBNDES/export/sites/default/bndes_pt/Galeri as/Arquivos/conhecimento/td/Td-87.pdf>. Acesso em 19 mai. 2015

PINTO JUNIOR, Mario Engler. Empresa Estatal: Função Econômica e Dilemas Societários. São Paulo: Atlas, 2010.

REQUIÃO, Rubens. Curso de Direito Comercial, v. 2. $18^{\mathrm{a}}$ ed., São Paulo: Saraiva, 1992.

SALOMÃO FILHO, Calixto. Regulação da Atividade Econômica (Princípios e Fundamentos Jurídicos). $2^{\text {a }}$ ed., rev. e ampl., São Paulo: Malheiros Editores, 2008.

SANTOS, Theophilo de Azeredo. As Sociedades de Economia Mista no Direito Brasileiro: Prática, Jurisprudência, Legislação. Rio de Janeiro: Forense, 1959.

SARMENTO, Daniel. Interesses públicos "versus" interesses privados na Perspectiva da Teoria e da Filosofia Constitucional. In: SARMENTO, Daniel (Org.). Interesses Públicos versus Interesses Privados: Desconstruindo o Princípio da Supremacia do Interesse Público. Rio de Janeiro: Lumen Iuris, 2005, pp. 23-116. 
SUNDFELD, Carlos Ari. Entidades Administrativas e Noção de Lucro. Revista Trimestral de Direito Público, São Paulo, n. 6, pp. 269-276, 1994.

VENÂNCIO FILHO, Alberto. A Intervenção do Estado no Domínio Econômico - O Direito Público Econômico no Brasil. Ed. Fac-similiar da de 1968, Rio de Janeiro: Renovar, 1998.

Sociedades de Economia Mista. In: LAMY FILHO, Alfredo; PEDREIRA, José Luiz Bulhões (Coord.). Direito das Companhias, vol. 2. $1^{\mathrm{a}}$ ed.. Rio de Janeiro: Forense, 2009. 